\title{
On the "Essential" Purposes of Limited Remedies: The Metaphysics of UCC Section 2-719(2)
}

\author{
Jonathan A. Eddy ${ }^{\dagger}$
}

Section 2-719(2) of the Uniform Commercial Code is an attempt to avoid the harsh results that might otherwise follow when a limited remedy "fails of its essential purpose." In this Article Professor Eddy finds that a "talismanic" approach, focusing more on the form of a limited remedy than on its intended purpose, characterizes the current case law dealing with section 2-719(2). He suggests that judicial analysis may be improved by a careful examination of the context of each particular transaction and a recognition that "failure of essential purpose" is theoretically separate from notions of "unconscionability."

Modern sales law derives principally from Article Two of the Uniform Commercial Code-Sales. ${ }^{1}$ Its provisions impose substantial warranty obligations ${ }^{2}$ upon sellers and afford an impressive array of remedies to buyers aggrieved by their breach. ${ }^{3}$ Both the warranty provisions and the remedy provisions of Article Two, however, are largely supplementary in nature: the parties are free to strike their own bar-

$\dagger$ B.A. 1966, Harvard University; J.D. 1969, University of Washington; Assistant Professor of Law, University of North Carolina at Chapel Hill.

1. The Uniform Coinnercial Code [hereinafter referred to as the Code] has been enacted in all states except Louisiana, and in the District of Columbia and the Virgin Islands. Although the Code sets forth basic parameters of the sales obligation, one must also consult specific legislation, particularly in the context of consumer transactions where local retail installment sales acts or similar legislation may apply. Increasingly, consultation of federal law has also become necessary, the most recent federal venture in this area being the Magnuson-Moss Warranty-Federal Trade Commission Improvement Act, 15 U.S.C. $\$ 2301$ (Supp. V, 1975). This Article restricts its attention to the Code provisions, although effects of the Magnuson-Moss Warranty-Federal Trade Commission Improveinent Act are noted at appropriate points.

2. UNIFORM COMMERCIAL CODE $\$ \S 2-313$ (express warranty); 2-314 (implied warranty of merchantability); 2-315 (implied warranty of fitness for particular purpose).

3. Id. § 2-711 contains an "index" of buyer's remedies. Most importantly, the Code rejects earkier "election of remedies" doctrine, which forced upon the buyer a choice between "rescission" (return of the goods and recovery of the price paid) and "affirmance" (allowing damages); under section 2-711 an aggrieved buyer may "revoke acceptance," without foregoing his right to damages. 
gain, altering or even eliminating the operation of the Code's rules. ${ }^{4}$ In practice, sellers often attempt to escape contractually from Codeimposed obligations. Conversely, aggrieved buyers often seek to escape the effect of their apparent bargaining-away of Code rights and remedies. Despite the practical importance of the frequent dispute these conflicting desires engender, some of Article Two's greatest intricacies obscure the exact parameters of sellers' freedom to disclaim warranty, limit remedy, and thus strike a "minimal bargain."

This Article will focus principally upon the role played by section 2-719(2), "relating to "failure of essential purpose," in establishing the limits of contractual freedom under Article Two. Attention will also be given, however, to the relationship between section 2-719(2) and the Code's unconscionability doctrine, sections 2-302 and 2-719(3).

To date, section 2-719(2) has found application in two types of cases. One involves the seller of a product that will undergo further processing in the hands of the buyer. The seller inserts a clause barring all remedy unless notice is given within a short time (e.g., 10 days) after delivery and, in any event, before processing. Alternatively, or additionally, liability for consequential damages is excluded and the buyer's recovery is limited to the amount of the purchase price. Following processing, a defect becomes evident. The buyer then sues, asserting that since the defect was undiscoverable while the goods were in an unprocessed state the limitation of remedy has failed of its essential purpose. In the second situation the seller employs a restricted "repair-or-replace" warranty and either refuses to repair or is unable to do so. The buyer then urges that the limited remedy has "failed of its essential purpose." Since section 2-719 seeks to encourage a method of lawfinding, rather than dictate a particular result, proper resolution of both types of dispute under the section requires a careful evaluation of the commercial context surrounding the parties' bargain. Only then can the role of the limited remedy within that bargain be understood. Yet courts routinely treat the "essential purpose" of a remedy as a self-evident inatter requiring no discussion. This analytic failure has generated at least three pernicious effects. First, the

4. See generally Weintraub, Disclaimer of Warranties and Limitation of Damages for Breach of Warranty Under the UCC, 53 TEXAS L. REv. 60 (1974); UNIFORM COMMERCIAL CODE $\$ \S 2-316$ (disclaimer of warranties); $2-718$ (liquidation or limitation of damages); 2-719 (contractual modification of remedies). All of these provisions are consistent with the Code's underlying purpose of permitting "the coutinued expansion of commercial practices through custom, usage and agreement of the parties." Id. § 1 $102(2)(b)$; the Code exphicitly embraces "freedom of contract" in section 1-102(3) and Comment 2 thereto.

5. The subsection provides: "Where circumstances cause an exclusive or limited remedy to fail of its essential purpose, remedy may be had as provided in this Act." UNIFORM COMMERCIAL CODE § 2-719(2). 
section has been applied to cases that might more properly be analyzed under other Code provisions, notably section 2-302 (unconscionability) or section 2-719(3) (unconscionable limitation or exclusion of consequential damages). Second, cases applying section 2-719(2) to repair-or-replace warranties reflect disagreement about the circumstances that lead a remedy to fail of its purpose. Third, again in the warranty cases, courts are divided over whether the failure of purpose of a limited remedy necessarily invalidates an exclusion of consequential damages.

In the next three sections of this Article, each of these issues shall be examined. An attempt will be made to isolate the factors contributing to the courts' sometimes confused handling of the issues and to suggest possible lines of analysis that may assist in a reasoned, consistent developinent of the principles underlying section 2-719(2).

\section{I}

UNDISCOVERABLE DEFECTS: UNCONSCIONABILITY vs. FaIlure of Essential Purpose

Although a fundamental premise of Article Two, both generally and in the specific area of limitation of reinedy, is "freedom of con-

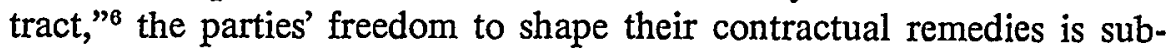
ject to a number of restrictions. ${ }^{7}$ Some appear simply to restate accepted common law doctrine. ${ }^{8}$ But two provisions, sections $2-719$ (2) and 2-719(3), break new ground:

Section 2-719. Contractual Modification or Limitation of Remedy. ....

(2) Where circumstances cause an exclusive or limited remedy to fail of its essential purpose, remedy may be had as provided in this Act.

(3) Consequential damages may be limited or excluded unless the limitation or exclusion is unconscionable. Limitation of consequential damages for injury to the person in the case of consumer goods is

6. Id. $\S \S 1-102(1), 1-102(2)(\mathrm{a})-(\mathrm{b}), 1-102(3)$ and Comment 2 thereto (as respects the Code generally); $\S 2-719(1)$ and Comment 1 thereto (limitation of remedy specifically).

7. Restrictions on "freedom of contract" are found generally throughout the Code: see, e.g., id. $\$ 1-102(3)$ and Comment 2 thereto; cf. $\$ \$ 1-201$ (3) ("Agrecment") and 1-201(11) ("Contract"). The most "notorious" inroad, of course, is section 2-302 ("Unconscionable Contract or Clause"), discussed in the course of the text.

8. Consider, for example, the distinction between valid "liquidated damage" clauses and invalid "penalty" clauses found in section 2-718(1). This distinction existed at common law. The Code rule, however, may alter somewhat the standard by which liquidated damage clauses are judged. See D. DobBs, HANDBoox on THE LAW of REMEDIES 821-23 (1973). For a thoughtful analysis of the venerable "distinction," see Macneil, Power of Contract and Agreed Remedies, 47 CORNell L.Q. 495, $499-513$ (1962). 
prima facie unconscionable but limitation of damages where the loss is commercial is not.

These innovative restrictions have not yet received a settled understanding.

According to one view, unconscionability under subsection (3) speaks to clauses unfair at their inception; correspondingly, failure of essential purpose under subsection (2) arguably refers to a remedy that, although initially fair, comes to operate unfairly under the circumstances to which it is later applied. ${ }^{9}$ Superficially, such a formulation does little more than track the Official Comment, which states that subsection (2) applies "where an apparently fair and reasonable clause because of circumstances fails in its purpose ...."10 The analysis adds, however, a false "chronlogical" relationship between the sections, which is absent from both the statute and the comment, and which may easily mislead. Contract clauses do not change their scope of application, having one application at the time of formation and another at the time of decision; therefore it is not strictly accurate to speak of an "initially" fair remedy that "later" operates unfairly. Rather, a clause is applicable to certain circumstances, and inapplicable to others. When a clause does apply, its application may be either fair or unfair.

Although conceptually a clause's scope of application is estabhished at the time of formation, practically a clause is rarely construed until a given set of circumstances has raised a dispute. ${ }^{11}$ At the time

9. J. WHITE \& R. SUMMERS, HANDBOOK OF THE LAW UNDER THE UNIFORM COMMERCIAl COde 380 (1972) [hereinafter cited as WhITE \& Summers]; 1 STATE OF NEW Yore Law Revision Commission, Study of the Uniform Commercial Code 584 (1955) [hereinafter cited as NEw York STUDY].

10. Comment 1 reads in full:

Under this section parties are left free to shape their remedies to their particular requirements and reasonable agreements limiting or modifying remedies are to be given effect.

However, "it is of the very essence of a sales contract that at least minimum adequate remedies be available. If the parties intend to conclude a contract for sale within this Article they must accept the legal consequence that there be at least a fair quantum of remedy for breach of the obligations or duties outlined in the contract. Thus any clause purporting to modify or limit the remedial provisions of this Article in an unconscionable manner is subject to deletion and in that event remedies made available by this Article are applicable as if the stricken clause had never existed. Similarly, under subsection (2), where an apparently fair and reasonable clause because of circumstances fails in its purpose or operates to deprive either party of the substantial value of the bargain, it must give way to the general remedy provisions of this $\mathrm{Ar}-$ ticle.

UNIFORM COMMERCIAL CODE $\$ 2-719$, Comment 1 . On the use of the Official Comments, see Skilton, Some Comments on the Comments to the Uniform Commercial Code, 1966 WIS. L. REv. 597. The reliance of the courts on the comments is obvious and probably excessive; as will be developed herein, section 2-719(2) and its comments well illustrate the dangers of such reliance. See text accompanyimg notes 38-50 infra.

11. Cf. Ellinghaus, In Defense of Unconscionability, 78 YALE L.J. 757, 802-03 (1969) [hereinafter cited as Ellinghaus]. 
of dispute, one then looks backward to the time of formation. To say that a remedy is "imitially" fair, or "apparently fair and reasonable" probably means no more than that it is easy to envisage some sets of circumstances in which the remedy operates quite equitably. The actual circumstances which have arisen and now call for the construction of the contract may be either the same or different from those "mitially" envisaged. If they are the same circumstances, then, as the remedy operates equitably, the likelihood of dispute is small. When they are different, and the remedy no longer appears to operate equitably, two distinct issues may arise. The first is whether, on a sensible construction, the remedy in fact applies to the circumstances that have arisen. Failure of purpose doctrine addresses this issue; it seeks to guide courts to sensible constructions by directing their attention to the underlymg purposes of the remedy in question, and thus dissuades thein from inechanical, literal applications having no justification in commercial understanding. If the clause im question has no application to the circumstances now confronted, there is no need for further analysis. But if a court finds that the clause was indeed intended to apply to such circumstances, a second issue may arise: is sucli a limitation unconscionable? ${ }^{12}$ The issue of failure of essential purpose is logically prior to the unconscionability issue-for it is best to decide if the clause applies to the facts in question before deciding if such application would be unconscionable. ${ }^{13}$

Sections 2-719(2) and (3) are best understood as seeking to impose an analytic process upon the courts. ${ }^{14}$ Section 2-719(2) "does no more than invoke intelligent construction of the contract clause ....",15 the ineans of assuring such construction is to scru-

12. Although it is true that the presence of such fair applications will make the burden of demonstrating unconscionability a difficult one to carry, this question is not answered conclusively simply by demonstrating that there are some fair applications of the clause in question. The concept of unconscionability is discussed in detail in the text accompanying notes 51-112 infra.

13. This illustrates a second way in which "chronological" language, which speaks of "initial" unconscionability and "later" failure of purpose, may unwittingly contribute to confusion.

14. This notion of an analytic process is consistent with the asserted tendency of Llewellyn to embody directives in Article Two requiring a method of answering an issue, rather than an answer to an issue. Compare Murray, The Realism of Behaviorism Under the Uniform Commercial Code, 51 ORE. L. REv. 269 (1972) [hereinafter cited as Behaviorism and UCC], with Danzig, A Comment on the Jurisprudence of the Uniform Commercial Code, 27 STAN. L. REv. 621, 631-32 (1975).

15. NEw YoRk STUDY, supra note 9, at 584. Professor Honnold, who wrote the analysis of this section for the Commission, continues: "so that it would be applied to those circumstances realistically contemplated by the parties." The "contemplation of the parties" may be a less restrictive construct than the "intention of the parties," but neither phrase does justice to the creative role of the court and the extent to which section 2-719(2) calls not for interpretation, but for construction, of the contract. Sec 
tinize the "purposes" underlying a clause. ${ }^{16}$ A three-step analysis may be suggested: 1) determination of the purposes underlying a provision; 2) determination whether application of the remedy in the particular circumstances will further those purposes (or whether there has instead been a "failure of essential purpose");3) if the clause does not fail of its essential purpose, determination whether furtherance of the purpose works an unconscionable result. Both failure of essential purpose doctrine and unconscionability doctrine impose upon courts the burden of ascertaining and evaluating the potential purposes of limited reinedy clauses. ${ }^{17}$ Thoughtful application of this analysis will require that the court be fully informed as to the commercial setting of the parties in the same manner as provided in section 2-302(2). ${ }^{18}$

Current case law indicates that courts frequently avoid the careful analysis that section 2-719 presupposes. For instance, in

UNIFORM COMMERCIAL CODE $\S \S 1-201(3),(11) ; 2-719$, Comment 1 (definitions of "agreement" and "contract"). In an early version of the Code, Llewellyn commented on the principles underlying contractual modification of remedies:

It is the parties who make agreements, but it is the law which determines the legal consequences of agreements . . . . And adequate minimum remedy at law is an inherent part of a contract's being legal. To some extent, transactions must fit themselves into the frames of the various types of legal structure which the law provides for the parties' use. . . .

National Conference of Commissioners on Uniform State LaWs, ReVised UniFORM SALES ACT-SECOND DRAFT $\$ 57$, Comment A(2)(a) (1941) (emphasis in original) [hereinafter cited as SECOND DRAFT 1941].

16. The "purposes" in question are the essential purposes of the limited remedy, "not of the . . . Code or of contract law or of justice or of equity." WhrTe \& Summers, supra note 9, at 380 . This statement must be read with care. To the extent that it distinguishes the question of the remedy's purposes from a generalized inquiry into the "best" or "most just" remedy, it is correct; however, if by the remedy's "purpose" the purposes of the particular contracting parties are meant, it appears erroneous. (Although the authors do not state they mean this latter interpretation, they fail to make clear that they do not.) Instead, the remedy's purpose should yield itself up to the court when the court has informed itself fully of the commercial trausaction and thus understands the "essential type" of the transaction before it. See J. MURRAY, ON Contracts $\$ 150$ (2d rev. ed. 1974) [hereinafter cited as MuRRAY]; Danzig, supra note 14, at 621, 625; Ellinghaus, supra note 11, at 796 passim. See also note 75 infra.

17. That unconscionability analysis calls for an equally "purposive" inquiry shall be argued more fully. See note 75 infra. I do not assert the wisdom of Llewellyn's "natural law" approach to commercial transactions, but merely that its influence is clearly present in section 2-719.

18. As Corbin said eloquently in another context: "The court must then supply the gap and allocate the risks in accordance with reason-that is, in accordance with custom, business practice, common feeling, the mores of the community. Often, these are not so plain that he who runs may read; the court must be advised by evidence as well as argument." Corbin, Recent Developments in Contracts, 50 HARV. L. REv. 449, 465-66 (1937).

Although section 2-719 has no hearing requirement, the comments do contain a cross-reference to section 2-302. Courts will presumably recognize this need at least when an unconscionability argument is presented under section 2-719(3). There may be cause for concern, however, as respects failure of essential purpose. 
Wilson Trading Corp. v. David Ferguson, Ltd., ${ }^{10}$ Wilson sold Ferguson a quantity of yarn. Ferguson knitted the yarn into sweaters, but the finished product, when washed, showed uneven variation in color. Ferguson refused to pay; when Wilson sued for the price, Ferguson counterclaimed for damages. The contract contained a disclaimer of any warranty extending beyond "delivery of good merchantable yarn of the description stated herem." The contract further provided:

2. No claims relating to excessive moisture content, short weight, count variations, twist, quality or shade shall be allowed if made after weaving, knitting, or processing, or more than 10 days after receipt of shipment. . . . The buyer shall within 10 days of the receipt of the merchandise by himself or agent examine the merchandise for any and all defects. ${ }^{20}$

The trial court noted the contractual time limitation and granted plaintiff's motion for summary judgment for the price. The appellate division affirmed without opinion, but the court of appeals reversed and remanded for trial. In its view a factual issue existed whether the defects alleged were reasonably discoverable before knitting and processing. ${ }^{21}$ If not, in the court's view, the time limit would "fail of its essential purpose," and the buyer would have available all Article Two remedies. ${ }^{22}$

19. 23 N.Y.2d 398, 244 N.E.2d 685, 297 N.Y.S.2d 108, 5 UCC REP. SERV. 1213 (1968). [Ed.] For the convenience of practitioners, citations to the UCC Reporting Service are included where applicable.

20. Id. at 401,244 N.E.2d at 686,297 N.Y.S.2d at 110, 5 UCC REP. SERV. at 1214 (emphasis in original).

21. On motion for summary judgment, the court correctly treated the parties' respective assertions as true. It might have been helpful, however, for the court to have elaborated on the concept of "reasonable discoverability." The statement that defects are "undiscoverable" is almost never true if taken literally. If taken more loosely, it is so elastic that it could cover all but "patent" defects. Presumably, the court intended that the "reasonability" of necessary discovery measures shall be the guide. The buyer affirmed that "a claim was made immediately upon discovery of the breach of warranty after the yarn was knitted and washed, and that this was the earliest possible moment that the defects could reasonably be discovered in the normal manufacturing process." Id. at 402, 244 N.E.2d at 687, 297 N.Y.S.2d at 111, 5 UCC REP. SERv. at 1215 (emphasis added). May not the presence of such a clause make it unreasonable to proceed through the normal manufacturing process without trial runs or testing? Cf. SECOND DRAFT 1941, supra note $15, \S 57 \mathrm{~A}$, quoted at text arcompanying note 50 infra; id. \$ 57A, Comment 2: "Such clauses [i.e., barring consequential loss] are not infrequent in sales of raws [sic] or semi-manufactured material for industrial use, and are reasonable, especially where a "trial run" can detcrmine defects to be present."

22. The opinion does not describe the contract as containing an explicit limitation of consequential damages. On the facts as given, therefore, the issue is not posed whether a failure of purpose of one limited remedy also avoids a limitation of consequential damage present in the same contract. See, e.g., Koehring Co. v. A.P.I., Inc., 369 F. Supp. 882, 14 UCC REP. SERV. 368 (E.D. Mich. 1974) (avoiding the clause excluding consequential damages as well). See also text accompanying notes 188-213 infra. 
Analysis of this case should begin with the recognition that there were pre-Code cases denying effect to such time limitations when "undiscoverable" defects caused loss. In a nearly identical case, Jessel v. Lockwood Textile Corp.,${ }^{23}$ the defendant sold material warranted to be washable, preshrunk, and color fast. The contract provided that all claims must be made in writing within 10 working days and before processing. The plaintiff manufactured the cloth into shirts before the defects were discovered. He then brought suit, alleging the defects were "not discovered or discoverable" until after manufacture. ${ }^{24}$ Operating without benefit of either "failure of essential purpose" or "unconscionability," the court found that "[w]hile it is competent for the parties to fix a debarment deadline on claims by the terms of their contract . . . we think that the effectiveness of such limitation should be determined in accordance with rules of reasonability."25

Jessel supports one of Llewellyn's favorite theses: that existing, pre-Code law already sanctioned inany results that critics feared would follow from the Code's novel doctrines. ${ }^{26}$ But Wilson does not support Llewellyn's corollary: that the forthright doctrines of the Code would lead to greater stability, predictability, and rationality by allowing courts to give explicit attention to the factors actually motivating their decisions. ${ }^{27}$ Jessel announced that a time limitation was "unreasonable" when applied to latent defects not discoverable during the period, although it might be valid as to patent defects. Wilson announced that a time limitation "failed of its essential purpose" when applied to latent defects not discoverable during the period, and indicated such a clause might be unconscionable as well. ${ }^{28}$ Both cases state their results; neither

23. 276 App. Div. 378, 95 N.Y.S.2d 77 (1950).

24. Id. at 378,95 N.Y.S.2d at 78 . On "discoverability" see note 21 supra.

25. 276 App. Div. at 379,95 N.Y.S.2d at 78.

26. See Statement of Karl Llewellyn in State of New York, Report of the LAW REVISION COMMISSION FOR 1954, at 159, 177-78.

27. Id. at 177-78; SeCond DrafT 1941, supra note 15, § 57, Comment A(3).

28. The court's entire analysis reads as follows:

[T] $t$ is unnecessary to decide the issue of whether the time limitation is unconscionable on this appeal for section 2-719 (subd. [2]) of the Uniform Commercial Code provides that the general remedy provisions of the code apply when "circumstances cause an exclusive or limited remedy to fail of its essential purpose". As explained by the official comments to this section: "where an apparently fair and reasonable clause because of circumstances fails in its purpose or operates to deprive either party of the substantial value of the bargain, it must give way to the general remedy provisions of this Article." (Uniform Commercial Code, § 2-719, official comment 1.) Here, paragraph 2 of the contract bars all claims for shade and other specified defects made after knitting and processing. Its effect is to eliminate any remedy for shade defects not reasonably discoverable within the time limitation period. It is true that parties may set by agreement any time not manifestly unreasonable whenever the code "requires any action to be taken within a reasonable time" (Uniform Commercial Code, $\S 1-204$, subd. [1]), but here the time provision eliminates all remedy for defects not discoverable before knitting and processing 
explams them. The talisman is changed, but the process remains talismanic.

One wonders whether application of a limitation clause in such circumstances is so unreasonable, so unfair, thus so unconscionable and lacking in any cominercially justifiable purpose that a court may appropriately state such results without elaboration. Is the result so evident that an explanation would belabor the point? An elaboration consonant with the three-step analysis suggested above, while reaching results sometimes at variance with the existing case law, will clarify the policies that courts ought to be pursuing in cases arising under section 2-719.

\section{A. Failure of Essential Purpose}

Normally, the Code allows a buyer a reasonable time to discover defects and make claims. ${ }^{29}$ Since the contractual clause in Wilson is phrased in terms of barring claims made more than 10 days after receipt or after processing, it invites the construction that it merely fixes an agreed reasonable time for imspection. ${ }^{30}$ This construction is bolstered by an additional clause in the contract providing that "buyer shall within 10 days of the receipt of the merchandise by himself or agent examine the merchandise for any and all defects." In the case of "undiscoverable" defects, ${ }^{31}$ a reasonable time ought not to start to run

and section 2-719 (subd. [2]) of the Uniform Commercial Code therefore, applies.

23 N.Y.2d at 404, 244 N.E.2d at 688, 297 N.Y.S.2d at 212-13, 5 UCC REP. SERY. at 1217.

29. UNIFORM COMMERCIAL CODE $\$ \S 2-513(1)$ (right to inspection before acceptance); 2-602 (manner of rejection); 2-607(3) (notice within reasonable time condition precedent to remedy); 2-608(2) (revocation of acceptance only within reasonable time).

30. Id. $\$ 1-204$ provides in part:

(1) Whenever this Act reqnires any action to be taken within a reasonable time, any time which is not manifestly unreasonable may be fixed by agreement.

(2) What is a reasonable time for taking any action depends on the nature, purpose and circumstances of such action.

If the clause were construed as a mutually agreed reasonable time for inspection, this section wonld provide an adequate basis for avoiding the time set. See id. $\$ 2-513$, Comment 7. One judge concnrred in the result in Wilson solely on this basis; the opinion of the court, however, explicitly disavows this rationale. 23 N.Y.2d at 403 n.1, 244 N.E.2d at 687 n.1, 297 N.Y.S.2d at 112 n.1, 5 UCC REP. SERv. at 1216 n.1. Insofar as the court saw larger issues of limitation of remedy posed by the clause, it was correct to go beyond section 1-204. Since, however, it confined its thinking about the clause to the one rationale to which section 1-204 is applicable, it never realized the full benefit of viewing the clause under section 2-719.

31. It is probable that the word "undiscoverable" gives the appearance of a distinction of kind to something that is really a matter of degree: difficnlty of discovery. Occasionally, this element of degree is recognized indirectly by employing the phrase "reasonably discoverable"; see note 21 supra. 
until discovery or until discovery "should have" occurred. ${ }^{32}$ Thus an agreenent intended to set a reasonable time for inspection, but not taking account of the actual opportunity for inspection, would "fail of its essential purpose" where the defects were undiscoverable. Where an agreement is intended to serve different purposes, however, a different conclusion might follow.

In Wilson the court, without even atteinpting to identify the essential purpose of the limited remedy, ${ }^{33}$ rejected the possibility that the clause might have purposes that would call for its application to undiscoverable defects. In the commercial world, however, there are many purposes that may be served by the application of such a clause to both discoverable and undiscoverable defects. For instance, the alternative form of the limitation (no claims after 10 days or after processing) might be intended to preclude liability for consequential loss. $^{34}$ Similarly, if it is very difficult to ascertain whether a problent stems from a defect in the wool once it lias been processed, the parties might reasonably allocate the risk of all such loss to the buyer, and thereby avoid lengthy, costly, and somewliat fortuitous litigation. Either of these purposes would call for the application of the clause to the Wilson facts. It is thus essential that the court be informed of the purposes of the clause through consideration of the coinmercial setting of the transaction. ${ }^{35}$

Another troubling aspect of the court's analysis is that it appears to equate absence of any remedy in these circumstances with failure of essential purpose. The comments to section 2-719 indicate that the section is intended to ensure that the contract assure "minimum adequate remedies" and a "fair quantum of remedy." But it hardly follows that the section requires a remedy under the contract for every situation in which a party suffers loss. ${ }^{37}$ The contract in question allowed normal Code remedies if a claim was made within the prescribed time limitation, but provided none under the particular circunt-

32. See UNIFORM COMMERCIAL CODE §§ 2-607(3), 2-608(2).

33. See note 28 , supra.

34. Only the "after processing" branch of the limitation appears at issue in Wilson. There is no reason to assume that the two branches of the rule need have the same rationale. Thus the 10-day limit (which corresponds with the additional 10-daysto-inspect clause) might be interpreted as not applicable to undiscoverable defects, while the after-processing limit might be interpreted to apply. Although the after-processing limit does not speak directly to consequential loss, there is no reason to require a special talismanic formula, if the clause adequately brings home to the buyer the risks in question.

35. See text accompanying notes $15-17$ supra.

36. See note 15 supra.

37. Such a construction would, inter alia, prohibit all exclusions of consequential damages, a result that is inconsistent with section 2-719(3). 
stances. If the purposes supporting the limited remedy are not facilitated by its application to a set of novel circumstances, then the remedy should be disregarded as having failed of its essential purpose. But if the clause operates to achieve its purposes, then whether those purposes are reasonable and whether the remaining quantum of remedy is "fair" pose issues of unconscionability, not failure of purpose.

A closely related analytic failure is embodied in the court's statement that the remedy must give way because it operates to deprive the buyer of the substantial value of the bargain. Here the court directly relies upon the official comment:

Similarly, under subsection (2), where an apparently fair and reasonable clause because of circumstances fails in its purpose or operates to deprive either party of the substantial value of the bargain, it must give way to the general remedy provisions of this Article. ${ }^{38}$

Unless this comment is applied very carefully, it assumes the answer to the very issue it should resolve. For a court to determine whether the buyer is being deprived of the substantial value of the bargain, the contours of that bargain must first be established. This process necessarily entails the construction of the limited remedy; limited remedies, lowever, inay affect the parties' bargain in quite different ways. Some, such as a limitation to repair or replacement of brand-name goods, may reasonably be construed as inposing a limited means of attaining a given end-for example, goods meeting the brand-name standard. ${ }^{30}$ In such a case, when the limited remedy fails to attain that end, we might say that the buyer is being deprived of the substantial value of the bargain. Other limitations, such as a limitation of consequential damages, are less easily regarded as a means to an end: they define the end-value of the bargain itself. ${ }^{40}$

38. UNIFORM COMMERCIAI CODE $\$ 2-719$, Comment 1 (emphasis added).

39. This is the sensible construction for such a limitation where the goods are standard goods; that is, goods of such a type that a known performance standard is routinely obtainable for such goods. Automobiles are a convenient example. See Beal v. General Motors Corp., 354 F. Supp. 423, 12 UCC REP. SERv. 105 (D. Del. 1973), discussed at text accompanying notes $155-57$ infra. In different circumstances, for instance where the goods in question are untried, a similar clause may serve a very different purpose. Cf. U.S. Fibres, Inc. v. Proctor \& Schwartz, Inc., 358 F. Supp. 449, 13 UCC REP. SERv. 254 (E.D. Mich. 1972), aff'd, 509 F.2d 1043, 16 UCC REP. SERV. 1 (6th Cir. 1975), discussed at text accompanying note 171 infra. The form of the clause is intelligible only in light of the type of transaction or situation in which it must be applied. The court must have "situation sense." See K. LLEwELLYN, The Common Law Tradrtion: Deciding appeals 121 (1960) [hereinafter cited as LLEWELLYN] and notes $15-17$ supra.

40. Limitations that are not in form limitations of consequential damages often serve this purpose as well. Depending on the situation, a limited repair warranty may serve the function. See U.S. Fibres, Inc. v. Proctor \& Schwartz, Inc., 358 F. Supp. 449, 13 UCC ReP. SERv. 254 (E.D. Mich. 1972), aff'd, 509 F.2d 1043, 16 UCC ReP. SERV. 1 (6th Cir. 1975). 
A brief consideration of the drafting history of section 2-719 may clarify this distmction. First, the present language of the comment goes beyond the text of the statute, which speaks only of failure of essential purpose. This was not always the case. The present form of Official Comment 1 traces to the May 1949 draft of Article Two. ${ }^{41}$ At that time it tracked language in the statute itself:

(2) Where circumstances cause an exclusive or limited remedy to fail of its essential purpose, as when it deprives the buyer of the substantial value of the contract or of the use or disposition for which the seller at the time of contracting had reason to know the goods were intended, remedy may be had as provided in this Act.. ${ }^{2}$

Second, this provision itself blends two provisions found in the 1944 draft. One provided that an expressly agreed exclusive reinedy was the sole remedy, except where circumstances caused it to fail of its essential purpose; ${ }^{43}$ the other provided for limitation of remedy to repair or replacement, except where this limitation deprived the buyer of the substantial value of the goods contracted for, or of the use or disposition for which the seller at the time of contracting had reason to know they were being procured.44 Finally, the language of the 1944 draft inay be located in two sections of the 1941 draft Revised Uniform Sales Act. ${ }^{45}$ In that Act section $57 \mathrm{~A}$ allowed a limitation of remedy to repair or replacement, provided that "the time required does not defeat the buyer's intended use or disposition . . . ."46 Section 57B disallowed limitation to repair or replacement "when the results thereof fail, in the circumstances of the contract and breach, to give the buyer the substantial value contracted for . . . ."47 Thus it appears that this language, when it entered the Code, was associated with a particular type of limited remedy, the "essential purpose" of which was to provide an economic means of assuring goods of warranted characteristics. ${ }^{48}$

In contrast, an exclusion of consequential damages does not define a means of obtaining the end-value of the parties' bargain, but itself aids in defining that bargain. ${ }^{48}$ In the same 1941 draft to which the

41. AMERICAN LAW INSTTIUTE-NATIONAL CONFERENCE OF COMMISSIONERS ON Uniform State Laws, Uniform Commercial Code May 1949 Draft $\$ 2-721$. There are some minor differences elsewhere in the commeut, not material to our purposes here.

42. Id. (emphasis added).

43. Joint Edtorial Commtttee, american Law Institute-National ConFerence of Commissioners on Uniform State Laws, Uniform ReVised Sales Act 122(2) (Proposed Final Draft No. 1, 1944) (Sales Chapter of Proposed Commercial Code).

44. Id. § 123.

45. SeCond Draft 1941, supra note 15.

46. Id. $\S 57 \mathrm{~A}$.

47. Id. $\S 57 \mathrm{~B}$.

48. See id. § 57, Comment $\mathrm{A}(2)$ (b).

49. This point is discussed more fully at text accompanying notes 188-213 infra. 
"substantial value" language may be traced in association with repairor-replace limitations, section $57 \mathrm{~A}(2)$ provided:

In furtherance of the principles of Section 57, a particularized term of the contract may in an appropriate case-

(2) Between merchants, provide that consequential damages are limited or excluded, notwithstanding that they flow from defects not reasonably discoverable by the buyer, if such defects are not due to avoidable fault on the part of the seller..$^{50}$

It is therefore unlikely that the drafters of section 2-719(2) regarded the Wilson situation, at least insofar as consequential damages are concerned, as one in which limitation of remedy "deprived the buyer of the substantial value of the bargain."

The language of the comment is consequently less helpful than it at first appears. The same analysis is required to determine whether there has been a deprivation of the substantial value as to determine whether there has been a failure of essential purpose. Moreover, as Wilson indicates, the comment has the potential affirmatively to mislead by encouraging courts to assume a particular bargain. When the limited remedy then fails to provide the substantial value of this assumed bargaim, the court, like the court in Wilson, asserts that the remedy has failed of its essential purpose-a conclusion that the actual commercial requirement for the remedy in question may not support.

Even if the limited remedy is achieving its purpose, it might be unconscionable. If so, painstaking analysis would shift the rationale of the case, but not the result. A careful examination of the alleged unconscionability of such a provision, however, will suggest that the provision might well withstand such an attack. Misanalysis of such cases under section 2-719(2) thus leads to improper results, not merely im1proper reasoning.

\section{B. Unconscionability}

Two code provisions bear on the unconscionability of a clause limiting or excluding consequential damages. The first is section 2-302, the Code's general provision respecting unconscionability:

(1) If the court as a matter of law finds the contract or any clause of the contract to have been unconscionable at the time it was made the court may refuse to enforce the contract, or it may enforce the remainder of the contract without the unconscionable clause, or it may so limit the application of the unconscionable clause as to avoid any unconscionable result. ${ }^{51}$

50. SECOND DRAFT 1941, supra note $15, \S 57 \mathrm{~A}(2)$ (emphasis added).

51. UNIFORM COMMERCIAL CODE $\$ 2-302$. 
The second is section 2-719(3), the Code's specific provision respecting unconscionable limitation or exclusion of consequential damages:

Consequential damages may be limited or excluded unless the limitation or exclusion is unconscionable. Limitation of consequential damages for mjury to the person in the case of consumer goods is prima facie unconscionable but limitation of damages where the loss is commercial is not.52

Reading these two provisions together, several matters are evident. First, as commentators have noted, neither section offers guidance on a definition of "unconscionability." ${ }^{3}$ Second, the language in section 2-302 supports the inference from the comments to section 2-719 that the test shall be applied "at the time [the contract] was made." Third, section 2-719(3), with its distinction between "personal injury in the case of consumer goods" and "commercial loss," makes an unconscionability attack upon a clause excluding consequential economic loss considerably more difficult than it might have been under section 2-302 alone. ${ }^{54}$

Faced with the need for a working definition of unconscionability, some courts have seized upon a formulation that links unconscionability to "an absence of meanimgful" choice for one party plus contract terms which unreasonably favor the other party." 55 So viewed, the concept has both a "procedural" element, which focuses upon the bargaining process, and a "substantive" element, which focuses upon the nature of the contested term. ${ }^{.6}$

52. Id. § $2-719(3)$.

53. WHTTE \& SUMMERS, supra note 9, at 116; Leff, Unconscionability and the Code-The Emperor's New Clause, 115 U. PA. L. REv. 485 (1967) [hereinafter cited as The Emperor's New Clause]. The substantial additional commentary includes: D. DobBs, supra note 8, at 705-15; Spanogle, Analyzing Unconscionability Problems, 117 U. PA. L. REV. 931 (1969); MURRAY, supra note 16, \$§ 352-53; Ellinghaus, supra note 11, at 757; Murray, Unconscionability: Unconscionability, 31 U. PrTr. L. REv. 1 (1969) [hereinafter cited as Unconscionability: Unconscionability]; Braucher, The Unconscionable Contract or Term, 31 U. PrTT. L. REv. 337 (1970); Speidel, Unconscionability, Assent and Consumer Protection, 31 U. PrTT. L. REv. 359 (1970); Leff, Unconscionability and the Crowd-Consumer and the Common Law Tradition, 31 U. PITT. L. REv. 349 (1970); Behaviorism and UCC, supra note 14, at 285.

54. WHITE \& SUMMERS, supra note 9, at 384.

55. Fleischmann Distilling Corp. v. Distillers Co., 395 F. Supp. 221, 232, 17 UCC REP. SERv. 678, 686 (S.D.N.Y. 1975); Williams v. Walker-Thoinas Furniture Co., 350 F.2d 445, 449, 2 UCC ReP. SERv. 955, 958 (D.C. Cir. 1965); Henningsen v. Bloomfield Motors Inc., 32 N.J. 358, 385-406, 161 A.2d 69, 84-96 (1960). The latter two cases were decided prior to the effective date of the UCC in the respective jurisdictions; however, in each instance the court addressed its attention to section 2-302, and the opinions have been cited and relied upon extensively both by commentators and post-Code decisions.

56. Professor Leff in The Emperor's New Clause, supra note 53, is the apparent originator of these terms, which have persisted in the subsequent literature. Not all colnmentators are in agreement that these two elements are strictly cumulative. Professor 


\section{Procedural Unconscionability}

Although "a commercial setting does not necessarily bar a claim of procedural unconscionability, 'it is the exceptional coinmercial setting where a claim of unconscionability will be allowed . . . "'57 Indeed, statements affirming the possibility of unconscionability in a commercial context appear largely as dicta in cases refusing to find unconscionability in such contracts. ${ }^{\mathrm{s}}$

This reluctance is not difficult to understand. "Procedural" unconscionability has itself been analyzed as consisting of two principal forms of abuse: "oppression" and "surprise." inability to bargain about a particular term; it unight result from "gross inequality of bargaining power," often in association with lack of an alternative source of supply. Courts have found these conditions where an average consuner dealt with a car dealer and the contract embodied a warranty disclaimer employed by all inajor doinestic autonobile manufacturers; ${ }^{60}$ where a ghetto dweller who was a marginal credit risk dealt with a retail merchant; ${ }^{61}$ and where a non-English speaker signed an English-language contract for a gas heater with a gas company, after

Murray, for instance, states quite clearly his view that substantive unconscionability alone may suffice (citing, interestingly, section 2-719(2) for this proposition). MURRAY, supra note 16 , at 749 . Some case law definitely tends in this direction, although usually the court could have developed procedural abuses from the facts, had it chosen to do so. Thus the cases do not present an absence of procedural elements, but only a failure to emphasize them. See, e.g., American Home Improvement, Inc. v. MacIver, 105 N.H. 435, 201 A.2d 886 (1964). Perhaps the best view is that the two factors operate as a "sliding scale": the more suspect the bargaining process by which a term entered a contract, the less "one-sidedness" should be tolerated. See Spanogle, supra note 53 , at 968.

57. Fleischmann Distilling Corp. v. Distillers Co., 395 F. Supp. 221, 233, 17 UCC REP. SERv. 678, 688 (S.D.N.Y. 1975), quoting County Asphalt, Inc. v. Lewis Welding \& Eng'r Corp., 323 F. Supp. 1300, 1308, 8 UCC REP. SERV. 445, 447 (S.D.N.Y. 1970). In the County Asphalt opinion, however, the quoted sentence concludes "absent undiscoverable 'latent defects." "Id. No explanation of this exception is given, although obviously this hedge was necessary to square the court's statement with Wilson. (County Asphalt was in federal court on diversity jurisdiction, and the district court was applying New York law.)

58. Some recent cases may indicate that the "surprise" element is coming into its own and that a more thoughtful application of sections 2-302 and 2-719 in commercial settings may be developing. See Schroeder v. Fageol Motors, Inc., 86 Wash. 2d 256, 544 P.2d 20 (1975).

59. UNIFORM COMMERCIAI CODE $\S 2-302$, Coinment 1: "The principle is one of the prevention of oppression and unfair surprise ...." See also authorities cited in note 53 supra.

60. Henningsen v. Bloomfield Motors, Inc., 32 N.J. 358, 161 A.2d 69 (1960). Henningsen is a pre-Code case, but its unconscionability analysis has been relied upon by both commentators and post-Code decisions.

61. Williains v. Walker-Thomas Furniture Co., 350 F.2d 445, 2 UCC REP. SERv. 955 (D.C. Cir. 1965) (another pre-Code decision much relied upon in post-Code discussions). 
the company's agent induced the purchaser's tenants to pressure the purchaser to sign. ${ }^{62}$ It is a far reach from such situations to Wilson Trading Corporation's dealing with David Ferguson, Ltd.

The second aspect of procedural unconscionability, "surprise," has greater prospect of employment in a cominercial setting. In Professor Murray's analysis the purpose of unconscionability doctrine in this area is to assist in determining the parties' true "circle of assent." ${ }^{33} \mathrm{Al}-$ though commercial entities nay generally have the ability to bargain about terms, they, like consunners, enter into inyriad "routinized" transactions in which attention is directed only to a few dickered terms. ${ }^{64}$ These dickered terms are then inserted into one or more forms evidencing the contract. Such forms, of course, contain further terms to which the parties have given no attention, often favoring the drafting party in a relatively one-sided manner. A theory giving effect only to the truly dickered terms might be too radical; $; 5$ Llewellyn argued for a more moderate position: that the parties specifically assent to the dickered terms, but also give a general, or blanket, assent to such further terms embodied in the documentation as are not "indecent." away in the fine print of a form-pad contract, even an objective theory of assent does not find a "manifestation of assent." persuasively that the proscription of "surprise" via unconscionability doctrine is one manifestation in the Code of Llewellyn's inodified theory of assent. ${ }^{68}$

Of all the branches of unconscionability doctrine, "surprise" theory is both the most easily reconciled with traditional contract doctrines and the most firmly articulated in the Code comments and Llewellyn's other work. Yet despite acceptance of the surprise theory by cominentators and its apparent applicability to many coinmercial transactions, two caveats

62. Brooklyn Union Gas Co. v. Jimeniz, 82 Misc. 2d 948, 371 N.Y.S.2d 289, 17 UCC REP. SERV. 689 (Civ. Ct. N.Y. 1975).

63. Behaviarism and UCC, supra note 14; Unconscionability: Unconscionability, supra note 53. A summary view of Professor Murray's analysis appears in MURRAY, supra note $16, \S \S 352-53$.

64. See Llewellyn, Book Review, 52 HARv. L. Rev. 700 (1939); Llewellyn, supra note 39 , at $362-71$.

65. Certainly snch an extensive reworking of assent theory would have seemed too extreme during the period when the Code was drafted; the more moderate approach is continued in Restatement (Second) of Contracts $\$ 237$ (Tent. Drafts 1-7, rev. \& ed. 1973), where the utility of such standard forms is explicitly recognized as a basis for enforcement of "nnknown" terms where they are not "unfair." Id., comments a-c. Llewellyn, supra note 39 , at 370-71.

66. Id.; Behaviorism and UCC, supra note 14.

67. MURRAY, supra note $16, \S 353$.

68. But see Schroeder v. Fageol Motors, Inc., 86 Wash. 2d 256, 544 P.2d 20, 18 UCC REP. SERv. 584 (1975). 
are in order. First, courts have shown little disposition to posit unconscionability solely on "surprise" in the absence of overtones of "oppression." gests that the presence of the limitation clause was in fact a surprise. ${ }^{70}$

Even if a court finds one or both of these types of "procedural" unconscionability present in a commercial setting, it remains to show that this "absence of meaningful choice" is coupled with "contract terms which unreasonably favor the other party" - that is, with "onesidedness."72 Accordingly, the substantive operation of the Wilson limitation clause inust be considered.

\section{Substantive Unconscionability: Undiscoverability is not Uncon- scionability}

As shown above, if a Wilson-type himitation clause is construed only as setting a reasonable time for inspection, it fails of its essential purpose where defects are undiscoverable and imspection would be futile; a discussion of its conscionability is unnecessary. If the clause is construed as one directed at exclusion of consequential damages or the elimination of all postprocessing remedies, however, it is quite inaccurate to say it fails of its essential purpose when it is applied to just those circuinstances where its enforcement will accomplish its purpose. ${ }^{73}$ In such a case, as in Wilson, the court must address the substantive unconscionability of a clause with such purposes. This analysis may consider the difference between discoverable and undiscoverable defects; but, as outlined below, this distinction will not suffice to dispose of the unconscionability issue.

More than a harsh result is required to make a provision substan. tively unconscionable. Exclusion of consequential damages, for instance, may work harsh results, yet the Code specifically accords prima facie validity to such clauses when they are directed at commercial loss. $^{74}$ Similarly, in a passage that has particularly mystified and

69. Although it is highly unlikely that Wilson involved a fully negotiated contract, no attention is given in the opinion to the probable form-pad nature of the contract. Of course, even if the clause were embodied in a form, that would not necessarily make its presence "surprising," if forms in the particular trade were commonly known to $\mathrm{cm}$ body sinilar clauses.

70. See cases cited in note 55 supra.

71. Brooklyn Union Gas Co. v. Jineniz, 82 Misc. 2d 948, 951, 371 N.Y.S.2d 289, 291, 17 UCC REP. SERV. 689, 692 (Civ. Ct. N.Y. 1975); Unconscionability: Unconscionability, supra note 53, at 23-24; Spanogle, supra note 53, at 945.

72. WHITE \& SUMMERS, supra note 9, at 381.

73. UNIFORM COMMERCIAL CODE \$ 2-719(3).

74. See, e.g., The Emperor's New Clause, supra note 53, at 499-501; Unconscionability: Unconscionability, supra note 53, at 40. 
irritated commentators, ${ }^{75}$ Comment 1 to section 2-302 states: "The principle is one of the prevention of oppression . . . and not of disturbance of allocation of risks because of superior bargaining power." Arguably, these factors might only point to the necessity of extreme one-sidedness. What seems more likely, however, is that unconscionability turns not only on a "one-sided" result, but also on an absence of "justification" for it. ${ }^{76}$ Accordingly, section 2-302(2) directs the court to receive evidence on the "commercial setting, purpose and effect" of an allegedly unconscionable clause. ${ }^{77} \mathrm{~A}$ two-step inquiry is thus suggested: 1) under what circumstances does the clause work a harsh result; and 2) when the clause does work such results, are there nonetheless useful purposes served by the clause, which provide an offsetting benefit? ${ }^{78}$ The utility of this dual analysis may be demonstrated

\section{UNIFORM COMMERCIAL CODE $\$ 2-302(2)$ :}

When it is claimed or appears to the court that the contract or any clause thereof may be unconscionable the parties shall be afforded a reasonable opportunity to present evidence as to its commercial setting, purpose and effect to aid the court in making the determination.

This section was added at the urging of theu-Professor Robert Braucher in 1951. See the account given in The Emperor's New Clause, supra note 53, at 542-43. It is evident, however, that the section attempts merely to clarify a process implicit in Llewellyn's views; the "acceptable" purposes are to be found in the "immanent law" of the particular type transaction:

[F]or purposes of analysis and for purposes of the best appellate judging we need to keep the type-situation-facts clear as a peculiar kind of facts with a peculiar message, nay, mission. I doubt if the matter has ever been better put than by that amazing legal historian and commercial lawyer, Levin Goldschmidt: "Every fact-pattern of common life, so far as the legal order can take it in, carries within itself its appropriate, natural rules, its right law. This is a natural law which is real, not imaginary; it is not a creature of mere reason, but rests on the solid foundation of what reason can recognize in the nature of man and of the life conditions of the time and place; it is thus not eternal nor changeless nor everywhere the same, but it is indwelling in the very circumstances of life. The highest task of law-giving consists in uncovering and implementing this immanent law."

Llewellyn, supra note 39, at 122 . When the court has informed itself of the "immanent law" of the situation, it will be clear whether the "essential purpose" of the limited remedy calls for its application in the particular case; it will also be clear whether the limited remedy (if its application is called for) works a conscionable result when viewed in context of the type transaction.

Opinions can and do differ about the appropriateness of Llewellyn's approach to a basic commercial statute. See authorities cited in note 14 supra. The most caustic appraisal of Llewellyn's theory, in the specific context of unconscionability, is found in The Emperor's New Clause, supra note 53, at 541-58. Although the critique has a measure of truth-and is often highly amusing-it is well answered in Ellinghaus, supra note 11. The metaphysical terms employed by Llewellyn are sure to put off many "hard-headed" lawyers; however, Llewellyn was by no means incapable of providing specific applications. See generally SECoND DRAFT 1941, supra note 15, §§ 57-57C and comments thereto.

76. See text accompanying notes 89-112 infra.

77. UNIFORM COMMERCIAL CODE $\$ 2-302(2)$, quoted in full at note 75 supra.

78. The defect of Wilson is that it ignores the possibility that there might be such purposes. The court must inform itself if it is to make a reliable judgment. 
by its application to problems involving discoverable and undiscoverable defects. Unfortunately, courts have failed to examine either the harshness of a particular clause or the underlying business decisions that may justify upholding the clause in such circumstances. The court in Wilson, for example, implied that such clauses are appropriate whenever defects are discoverable, but are inappropriate when defects are undiscoverable. This simple dichotomy was apparently based on the court's perception of the relative economic losses involved-a perception that does not withstand analysis.

Consider, for example, the operation of the Wilson limitation clause to transactions involving yarn with discoverable defects. If the defects are in fact discovered, the limitation clause certainly does not work a harsh result; the buyer will receive the full value of the bargain by making a timely claim against the seller. Even if a limitation of consequential damages were also included, the buyer would not be substantially harmed; since the clause calls for claim prior to processing, the discovery of the defect eliminates all significant consequential loss. On the other hand, losses may be high where the defect is undiscoverable. The buyer will already have processed the goods, making compliance with the notice limitation impossible; the act of processing will likely result in consequential damages in excess of the direct loss on the transaction.

The contrast between these two situations might suggest treating cases involving undiscoverable defects differently, since the loss in such cases is great. Yet to base the dichotomy on the difference in loss suffered overlooks the fact that loss may also be great where defects are discoverable. If the buyer fails actually to discover a "discoverable" defect, exactly the same consequences may ensue as when a defect is undiscoverable. Courts that adopt the Wilson dichotomy seem untroubled by the prospect that buyers will be left uncompensated for such losses. Accordingly, such courts inust be premising their distinction not on loss suffered, but rather on some perceived justification for leaving this loss with the buyer when the defect is discoverable. This justification inust also be perceived to apply only when the defect is discoverable.

One justification that ought to be examined is the notion that if the defect is discoverable, the loss is one which the buyer could avoid. Although it is impossible to identify with certainty all the considerations that may have inotivated the Wilson court, its distinction between discoverable and undiscoverable defects is consistent with a justification of "avoidability."79 Although large uncompensated losses must be

79. The distinction has been made in several cases decided after Wilson. See, e.g., Neville Chem. Co. v. Union Carbide Corp., 294 F. Supp. 649, 5 UCC Rep. Serv. 
borne by the buyer who fails to discover discoverable defects, the result is not harsh since the loss could have been avoided. The failure to do so must be the result of either faulty inspection by the buyer or a deliberate decision to forego inspection. In either case there is little mjustice in allowing the parties to agree that the buyer shall bear all losses stemming from such causes.

As a further justification, the court may have believed that such limitation clauses serve to minimize loss where defects are discoverable. ${ }^{80}$ Since this loss mimimization function cannot be served where the defects are undiscoverable, the limitation "fails of its purpose" and therefore should not be given effect. The seductive appeal of both these propositions, however, dissipates upon reflection. Indeed, the entire Wilson approach ignores the most significant analytical step: if loss occurs, is it fair to leave it upon the buyer? As indicated above, an analysis of the harshness of the result cannot end the mquiry; the purpose behind the clause must be considered.

\section{a. Avoidability}

It does not follow that because loss is not avoidable, the parties should not be free to allocate it as they see fit. One can inagine a spectrum with risks avoidable only by the seller on one end and risks avoidable only by the buyer on the other. In between fall two other classes of risks: those avoidable by both parties and those avoidable by neither. It is difficult to see what is unfair about two contracting parties shifting a risk from either class of risks in this central portion of the spectrum to one or the other party. If there is a type of risk allocation that should be subjected to special scrutiny, it is probably the shifting to one party of a risk that only the other party can avoid.

Thus, to say that discoverable defects give rise to risks avoidable by the buyer diverts attention from the fact that such risks are also avoidable by the seller. Since the risk can be avoided by either party, the parties should be free to agree which of them shall have the burden of doing so. ${ }^{81}$ Conversely, loss arising out of undiscoverable defects

1219 (W.D. Pa. 1968), aff'd in part, vacated on other grounds, 422 F.2d 1205, 7 UCC ReP. SERv. 81 (3d Cir. 1970), discussed at text accompanying note 94 infra; Earl M. Jorgensen Co. v. Mark Constr., Inc., 540 P.2d 978, 17 UCC REP. SERv. 1126 (Hawaii 1975); Majors v. Kalo Laboratories, Inc., 407 F. Supp. 20, 18 UCC REP. SERv. 592 (M.D. Ala. 1975).

80. Since Wilson did not decide the unconscionability issue and did not fully analyze the failure of purpose of the clause, it is impossible to identify with certainty all of the courts' motivations.

81. That is, by encouraging inspection-action which would be futile where nothing could be discovered in any case. The concept is explored more fully in the text accompanying note 83 infra. 
represents a risk that neither party can avoid. Here again the parties should be free to decide which party shall bear the risk. ${ }^{82}$

\section{b. Loss Minimization}

Related to the issue of avoidability is the question of loss minimization. The Wilson court may have assumed that the function served by a limitation clause is to "minimize" loss. Although this purpose may be effected where the defects are discoverable, it is frustrated where they are undiscoverable, arguably justifying Wilson's conclusion that the remedy fails of its essential purpose. But loss is only a particular type of cost. At least so long as the loss is only economic, there is no certainty that the parties will, or should, treat it differently from any other type of cost. ${ }^{83}$ In the Wilson transaction, for example, each party faced a business decision that involved balancing several potential factors: the cost of risk avoidance, ${ }^{84}$ of risk materialization, ${ }^{85}$ and the effects upon price and demand of shifting some or all of such burdens to the other party.

When the defects in question are not discoverable, the above analysis is changed in certain details, but not in essence. So long as defects were discoverable, each party had the option of risk-avoidance. Now risk-avoidance is no longer possible. Each party's decision is reduced to one of bearing the costs of risk-materialization or else of shifting those losses completely to the other party. Wherever the now unavoidable costs finally rest, the party who will have to bear them must consider that cost in the bargaiming process and determine if the particular venture is still attractive. Loss minimization, in the larger

82. "Unconscionability" may result from a social judgment (1) that it is not feasible for one party to spread a loss or (2) that the loss is not truly "fungible." Both elements enter into the prima facie unconscionability of limitations of liability for personal injury in the case of consumer goods under section 2-719(3). Such a case stands in direct opposition to the situation where two commercial entities agree to allocate consequential economic loss, both parties having some ability to avoid the loss and some ability to finance the loss. Not surprisingly, the prima facie legal "rules" for the two situations are also in opposition. UNIFORM COMMERCIAL CODE $\$ 2-719(3)$.

For the courts that have focused upon the buyer's ability to avoid, a neat twist may be posed by refocusing attention upon the seller's power to avoid. How is it, one might ask, that it is permissible for a seller to limit liability for loss arising out of defects that he could have discovered, but not out of those that he could not have discovered? This would merely repeat from a changed perspective the error of looking at "avoidability" by one party in isolation.

83. See note 82 supra.

84. For either party these costs primarily consist of the cost of inspection.

85. For the seller these might imclude costs of settling, defending, or paying claims, as well as more generalized costs such as loss of good will. The buyer might face similar costs arising out of the sale of its own defective products downstream, or at least the costs of lost or wasted production. 
economic sense, is thus not really frustrated by upholding limitation clauses in undiscoverable defect cases.

\section{c. Justifying the Exclusion of Remedies}

At this point certain distinctions may usefully be made between the exclusion of consequential damages and the exclusion of all remedies following processing. Most of the arguments made thus far are more clearly applicable to exclusion of consequential damages alone. It may well be that the error of the plaintiff in Wilson was excessive greed in suing for the price, rather than letting things be (with the consequential loss resting for the moment on the defendant). The clause, of course, by its terms precluded all remedies, and some purposes can be imagined that would support this result. As suggested earlier, suppose that following processing it is virtually impossible to tell whether defects $\mathrm{m}$ the finished goods stem from a defect in the raw material or in the process itself. Suppose further that although it is nearly impossible to tell in a particular case the cause of the defect, statistically the probability of defects from processing itself is significantly greater than defects in the raw material. In such a case, a clause restricting remedy to refund of the purchase price would be inadequate froin the seller's viewpoint, since the seller might have either to forego the price or be subject to costly disputes in a substantial number of cases where perfectly good material had been sold. These suppositions, if correct, would provide a justification for even a drastic application of the limitation clause-a complete bar of remedies. A less drastic application of the limitation, barring only consequential damages, is much more easily justified. ${ }^{86}$ To find that a clause is offensive in its most drastic form might provide a reason for limiting its application to avoid an unconscionable result, but not for voiding the limitation entirely. ${ }^{87}$

In sum, courts that have drawn a distinction between discoverable and undiscoverable defects appear moved by three considerations: ${ }^{88}$ first, the impact-large, uncompensated losses-of short limitation clauses on the buyer; second, the buyer's inability to avoid this loss; and third, the problem of applying certain policies, particularly loss minimization, that appear to justify the clause when the defects are

86. This less drastic alternative may be justified simply by arguments of reasonable loss allocations. See text accompanying notes 81-85 supra. The exceptional situations calling for a counter-rule are discussed in the text accompanying notes 89-112 infra.

87. Section 2-302(1) was carefully drafted to encourage this type of remedial flexibility. Obviously, the same flexibility should exist when a question of unconscionability arises under section 2-719.

88. See, in addition to Wilson, cases cited in note 79 supra. 
discoverable, but not otherwise. Yet none of these grounds withstands careful scrutiny. That the buyer suffers a large, uncompensated loss is not in itself determinative, as the courts appear willing to concede when the loss is avoidable by the buyer. A distinction based on avoidability has a superficially "equitable" appearance, but in fact may inerely upset a loss allocation arrived at by the parties-hardly an equitable result. Finally, the judicial disruption of the bargain cannot be premised on loss minimization. Loss, so long as it is economic, is merely a subspecies of cost; the division of functions that will mimimize cost in a particular transaction can only be ascertained after detailed consideration of the parties' specific environments. Our economic system is utterly indifferent to how the parties divide such functions; our political system believes this type of decision is best made by the immediate parties; and our contract system provides the means for those parties to reach and enforce their decision. One might expect a court of last resort to depart from such basic premises cautiously and only after dehiberate analysis.

Thus, Wilson displays a number of weaknesses typical of section 2-719(2) case law. Attention is never carefully directed to the types of purposes that the limited remedy might serve. As a result, several purposes that would have been effectuated by application of the clause in the circumstances are not even considered. Since they are not considered, neither are they scrutinized under an unconscionability analysis. Had they been scrutinized for unconscionability, a limitation of consequential damages would probably have been upheld and an exclusion of all remedies could possibly have been upheld. Instead, the clause was deemed to fail of its unstated purpose, apparently on no more substantial ground than that the defendant suffers loss for which the Code would usually provide compensation, but for which the contract as written does not. With very minimal analysis, a rewriting of the parties' apparent intended bargain is worked. In the process the court demonstrates neither that their apparent bargain was not their actually intended bargain, nor that their bargain was in any way unfair under the circumstances of the trade.

\section{Unconscionability: "Fault" and Risk Allocation}

This is not to say that all limitations of consequential damages are conscionable; nor should the preceding discussion be taken to mean that such factors as avoidability of loss or loss minimization are irrelevant to the issue of unconscionability. Rather, "undiscoverability," and the related issue of loss avoidance by the buyer, are simply not in themselves determinative. A more refined analysis is necessary. 
An important factor is "fault." It is interesting to read cases such as Wilson against the backdrop of Llewellyn's 1941 Second Draft of the Revised Uniform Sales Act. In place of section 2-719(2), that draft provided:

In furtherance of the principles of Section 57, a particularized term of the contract may in an appropriate case....

(2) Between merchants, provide that consequential damages are limited or excluded, notwithstanding that they flow from defects not reasonably discoverable by the buyer, if such defects are not due to avoidable fault on the part of the seller. ${ }^{89}$

The comment adds:

Such clauses are not infrequent in sales of raw or semi-manufactured material for industrial use, and are reasonable, especially where a 'trial run' can determine defects to be present. Nor is it unreasonable for the risk of unknown and unavoidable defects to be allocated by a clearly particularized term. On the other hand, neither a general disclaimer of warranty nor a term limiting damages is ground for excusing a seller for a type of damage which good faith forbids such clauses to be read as including: a damage arising out of seller's avoidable fault, and out of buyer's reliance by the fact of taking delivery, on the absence of such fault..$^{90}$

This comment displays the same tension between an ambiguity concerning "procedural" and "substantive" abuses that Professor Leff so ably criticized in his examination of section 2-302. ${ }^{91}$ Standing alone, the statement that a generalized term cannot exclude liability for defects arising out of seller's fault $t^{92}$ might lead to the negative inference that a particularized term could exclude such liability. But the statement does not stand alone. It stands in alleged opposition to the statement that a specific term may allocate risk of unavoidable defects to either party. "Unavoidable defects" presumably does not equate with "seller's avoidable fault"; rather, it is in opposition. Thus we have not one, but two, distinctions between the two statements. This dual distinction, in turn, raises the question whether the "true distinction" is procedural, opposing generalized to particularized terms, with the ain of avoiding surprise, or substantive, opposing seller's fault to unavoidable defects, with the aim of imposing a minimum core of seller's liability.

89. SECOND DRAFT 1941, supra note $15, \S 57 \mathrm{~A}$.

90. Id. $\$ 57 \mathrm{~A}$, Comment (A) (2) (emphasis added).

91. The Emperor's New Clause, supra note 53, at 485. Professor Leff is uncharacteristically kind to section 2-719 and its comments. Id. at 518-19.

92. This analysis is analogous to that concerning the prevention of surprise. See text accompanying notes $58-72$ supra. 
Nor does the comment elucidate the concept of "avoidable fault" itself. Fault is one of those "emotionally satisfying incantations", ${ }^{33}$ it poses the constant danger of seeming to justify a result without having contributed to its explanation. This fear is especially valid in commercial life, where fault may assume strange and unfamiliar forms. Reliable criteria must therefore be more specific than "fault." Keeping in unind both that Llewellyn may have regarded fault as a touchstone to indicate those instances where seller could not avoid liability and the felt need for more specific criteria, an analysis of the cases is helpful.

Neville Chemical Co. v. Union Carbide Corp. ${ }^{94}$ provides an excellent illustration of "avoidable fault." Union Carbide sold to Neville an unsaturated hydrocarbon oil produced at a West Virginia facility. The production process, however, involved use of a petroleum by-product, dripolene, which Union Carbide obtained from several of its other plants, including one in Texas. Neville used the Union Carbide oil in producing resims, which it sold to customers who incorporated them into such diverse products as varnish, floor tile, and chewing gum. The oil was purchased under a requirements contract signed early in 1963, which provided that notice of claims must be given within 15 days of receipt of shipment, that Neville assumed all risk and liability for the results obtamed by the use of the oil in the manufacturing process or in combination with other substances, and that no claim should exceed the purchase price of the material in respect to which the claim is made. Following a period of happy relations, Neville began to receive complaints from its customers that the products into which the resin had been incorporated emitted a persistent and foul odor. Eventually this odor was traced to the presence of ethyl acrylate in the dripolene obtaimed by Union Carbide from its Texas plant during the latter portion of 1963.

Focusing solely on these facts, Neville Chemical bears a resemblance to Wilson. But Neville Chemical mvolves further and quite different facts which bear directly on the concept of "avoidable fault." To begin with, despite the language indicating that Neville bore all risks of the manufacturing process, and risks arising from combination with other substances, the oil in question was developed by Union Carbide in specific response to Neville's needs. In the course of development several samples were submitted to, and rejected by, Neville. When at last a suitable product was created, Neville restricted its initial order

93. The Emperor's New Clause, supra note 53, at 485 (applying the phrase to "unconscionability").

94. 294 F. Supp. 649, 5 UCC REP. SERv. 1219 (W.D. Pa. 1968), aff'd in part, rev'd in part, 422 F.2d 1205, 7 UCC REP. SERV. 81 (3d Cir. 1970), cert. denied, 400 U.S. 826 (1970). 
to one barge shipment of 300,000 gallons. That shipment being satisfactory, during following months Neville placed 10 more orders of the same size. Only then did Neville enter into a year-to-year requirements contract, calling for an estimated 1,500,000 gallons-per-year. Thus although Neville "bore all risk of the manufacturing process," it agreed to purchase the given product and bear the associated risks only after an extensive, and cooperative, development program that afforded an opportunity to assess those risks.

None of the oil shipments during the development period or during the early months of the requirements contract contained ethyl acrylate. During 1963, however, Umion Carbide's Texas facility altered its production processes, resulting in the introduction of ethyl acrylate into dripolene originating at that plant. Union Carbide was aware not only of the change, but also of the risks it created. According to a memorandum circulated internally at the Texas plant, the West Virginia facility "has been alerted that the Seadrift [Texas] dripolene will contain small quantities of acrylate. They have agreed to accept the material on a trial basis and will let us know if any problems arise." ${ }^{\text {95 }}$ Despite its knowledge of the risk, Union Carbide took no steps to advise Neville. Moreover, when Neville first alerted Union Carbide of its custonners' complaints and specifically advised that it suspected some change in the composition of the oil, Union Carbide did not disclose its knowledge of the risk, buttressed by results of an analysis made upon a sample of problenn floor tile submitted to it.

Neville sued on theories of negligence and breach of warranty, seeking to recover its own business losses and expenses as well as the cost of settling claims by its customers. The trial was conducted in two stages: the hability issues were submitted to the jury on special interrogatories, and the danage issues were then tried. Following a verdict against Union Carbide, posttrial motions for judgment n.o.v. and a new trial were submitted, ${ }^{96}$ premised in part on the theory that the contractual provisions precluded plaintiff's recovery. ${ }^{97}$ The trial court held that the 15-day time limitation for claims was "inanifestly unreasonable" under section 1-204, having concluded that the limitation of damages to return of the purchase price was "wholly inadequate in the case of a latent defect not discoverable within a reasonable period after receipt of shipment," and that the reinedy was "far below a bare ininimuin in quantuin" and thus "ineffective under section

95. 422 F.2d at 1208 n.1, 7 UCC REP. SERv. at 84 n.1.

96. A further motion to amend the verdict was submitted and granted; the opinion provides no particulars.

97. Uniou Carbide also attacked plaintiff's proof of causation and the propriety of the damage awards under Pennsylvania law. The latter challenge was successful on appeal, forcing a remand. 422 F.2d 1205, 7 UCC REP. SERY. 81 (3d Cir. 1970). 
2-719(2)."98 The jury verdict against Union Carbide being found proper on both warranty and negligence theories, the defendant's motions were denied.

The district court improved upon Wilson by identifying what it conceived to be the purpose of the limitation: restoration of the status quo ante, which was not possible under the circumstances of the case. If one accepts this premise, the conclusion that the reinedy "fails of its essential purpose" is correct. Reading the clause in the context of the entire contract and transaction, however, there is little doubt that the clause was intended rather to allocate all risk of consequential loss to the buyer. ${ }^{99}$ Had the latter interpretation prevailed, an "essential purpose" would have been furthered by application of the clause in the particular case, thus necessitating that further attack proceed along unconscionability lines. And as suggested above with respect to Wilson, an allocation of consequential loss to the buyer is not unconscionable sinply because the loss stems from undiscoverable defects. ${ }^{100}$

Neville Chemical reaches the correct result, but the district court fails in its analysis to place sufficient emphasis on the most pertinent facts. Although the opinion recites a number of facts that bear directly on Union Carbide's "avoidable fault," the court fails to develop this aspect of the case. Instead, it is content to rest its decision on the overly broad basis that the defects were undiscoverable. In contrast, the Third Circuit's opinion on appeal appears to see only those facts: the decision is affirmed as to liability issues, but solely on the ground of Union Carbide's negligence, and the ineffectiveness of the disclaimer and limitation of remedy provisions to avoid negligence liability. The court found it unnecessary to consider defendant's arguments attacking plaintiff's breach of warranty case; further, the court indicated some doubt as to the applicability of section 2-719 to a negligence theory.

Union Carbide's knowledge of the shift in production process makes Neville Chemical a very different case from Wilson: more than

98. 294 F. Supp. at 655,5 UCC REP. SERv. at 1224. The language "minimum of quantum" reflects the Official Comment to section 2-719 ("minimum adequate remedies," "fair quantum of remedy"), quo'ed in full at note 10 supra. As noted at text accompanying notes 38-50 supra, this language, which does not appear in the statute itself, lends itself to misapplication.

99. It will be recalled that the contract embodied, in addition to the time limitation and damage limitation, a clause placing "all risk or liability for the results obtained by the use of any material . . . in manufacturing process . . . or in combination with other substances" upon buyer; this clause immediately precedes the limitation of recovery to purchase price. Significantly, the trial court opinion contains no discussion of this provision.

100. See text accompanying note 79 supra. The district court also drew an analogy to inadequacy of replacement of a defective part, as in Henningsen v. Bloomfield Motors, Inc., 32 N.J. 358, 161 A.2d 69 (1960). 
an undiscoverable defect is involved. Indeed, comparison of the two cases indicates that the concept of "undiscoverable defects" should be refined. Very few defects are literally undiscoverable; rather, "undiscoverable" is a relative term that may refer to a situation in which discovery is difficult, ${ }^{101}$ in which certain consequences of a defect may not be readily apparent until a latter stage in the manufacturing or distribution process, or in which inspection at a particular stage will destroy the economic value of the goods. ${ }^{102}$ Thus, although in each of the above instances the defect is arguably "undiscoverable," it is true neither in an absolute sense nor in the sense that the defects are equally undiscoverable for all parties at all stages in the manufacturing and distribution process.

Neville Chemical illustrates the situation in which the defect is not readily apparent until a later stage of manufacture and distribution. Of course, investigation of the oil could have been carried out in either party's hands; presumably, a chemical analysis could have revealed the presence of the ethyl acrylate. In this sense the case seems to fit within the first category-where discovery is difficult. Yet would the presence of the ethyl acrylate have been recognized at the time of discovery as a "defect"? Assuming that it would not have been-a reasonable assumption given the complexities of the modern chemical industrythe defect becomes something that can be discovered only "downstream." In this event the probable timing of the discovery would strengthen the soundness of putting the risk of such defects on the purchaser. Indeed, the contract in Neville Chemical very clearly put such risks on the purchaser in the first instance, and the purchaser, very conscious of bearing this risk, appropriately limited its exposure by a slow process of testing and imcremental orders. Only after the completion of a thorough risk assessment did the purchaser agree to a long-term requirements contract.

Of course, had the oil, with no change in its composition, later proved defective, the purchaser alone would have borne the risk. ${ }^{103}$

101. An example is where microscopic defects are present.

102. An example is where goods are sold for resale in sealed containers.

103. In such a case the "defects" that later appear must be attributable to changes in buyer's processes or to the inadequacy of buyer's original testing. These are risks that reasonably may be allocated to buyer. Neville itself represents the other end of the risk spectrum: an intentional change in the seller's process, creating known risk of loss to buyer. The hardest case is posed by an unintentional change in the seller's process. One might be tempted to say that this question must be answered by reference to seller's fault. Although "fault" is evident in Neville Chemical in the failure to notify of the changed process, fault could also be present simply in the process itself. But it is less clear that the parties could not reasonably have allocated the risk of seller's negligence to buyer; both parties were functioning in a commercial context of which the contract was only a part. Commercial good sense had already provided an incentive 
Moreover, the contract contained an escape clause, which provided that in the event a "change in the character of Dripolene, for any reason whatsoever, render(s) it impossible ... for [Carbide] to produce material conforming to the specification limits," Carbide would be released from its obligation. ${ }^{104}$ Thus, it appears that had there been an intentional, notified change in process Union Carbide would not have continued to be bound, and had later risks of the same product developed, Union Carbide also would not have been liable. The risk that the contract did not place upon Neville, however, was that Carbide would change its production process without notice, potentially rendering Neville's extensive testing useless.

It is interesting to note that this analysis of Neville Chemical partly eases the tension between "procedural" and "substantive" considerations identified in the comment to the 1941 draft. For Neville's substantive fault is inextricably bound up with procedural considerations. Neville Chemical nicely illustrates Llewellyn's reasoning that a "generalized disclaimer or limitation of remedy" cannot avoid responsibility for fault: the disclaimer or limitation is sufficient only to subject the purchaser to the risk that the given formula may produce poor results or, perhaps, that occasionally the fornula may be unintentionally departed from. It is not sufficient to make the purchaser aware that he must continually be testing to see if the seller has chosen to change the characteristics of the oil. Fault here consists of failure to bring home to the purchaser the risk that the seller is now imposing; if the seller did notify, it is probable that there would be no "fault."

Neville Chemical represents an extreme case of imbalance between the parties' relative ability to avoid the specific risk in issue. Neville's "ability" was negligible, not because it could not in an absolute sense avoid the risk, but because it had been led to believe that it had already avoided the risk. Union Carbide, on the other hand, had a complete opportunity to initiate steps to avoid the risk, because it knowingly engaged in the specific risk creation.

The best way, then, to particularize the amorphous concept of fault is to focus upon this narrower question of the relative ability of the parties to engage in risk-avoidance or make provisions for risk-materialization. Where the parties do not have roughly equal opportunities to

to Union Carbide to make a good product, and Neville, with knowledge of Union Carbide's general "track record," might have been willing to rest with the business sanction and forego the legal one.

Such difficulties as establishing causation in complex law suits can only increase the latitude a party may enjoy iu exculpating himself from liability for conduct that a trial court might later be convinced was negligent. Cf. J. FrANK, CourTs oN TRIAL, ch. 3 (Atheneum ed. 1963).

104. 422 F.2d at 1208,7 UCC REP. SERV. at 84. 
engage in these forms of planning, an attenipt by the party with the planning opportunity to shift the burden of planning failure to the party without planning opportunity should render the limitation clause suspect. Note that this standard would result in less intervention by the courts into the parties' bargain. A rule thus formulated calls for judicial nonintervention in a number of instances, like Wilson, where the courts are now intervening, misled by an overly broad rationale.

In addition to imbalance in the opportunity for risk-avoidance, another instance where a risk-shifting term nuay fail as unconscionable is the case in which a significant disparity exists in the parties' abilities to finance risk-materialization. A set of cases that involves both policies deals with mislabeled, mispackaged, or otherwise defective seeds. ${ }^{105}$ In the typical scenario the purchaser sues the seed distributor following crop failure, and a limiting clause, usually either a time limit for inspection or an exclusion of consequential damages, is asserted in defense. Defendants have been notably unsuccessful in such cases: time limits have been held unreasonable under section 1-204;106 limitations of liability have been held void as against public policy, ${ }^{107}$ ineffective to limit liability for negligence, ${ }^{108}$ to fail of their essential purpose, ${ }^{109}$ or to be unconscionable, ${ }^{110}$ or simply not to be part of the contract. $^{111}$ The inequality of opportunity to avoid risk arises from the nature of the seeds: it is difficult, sometimes nearly impossible, to differentiate particular types of seed in their seed state; and if it is possible, the differences may exceed the expertise of the purchaser. To the extent, then, that discovery is available, a seed company holds a decided advantage in ability; more significantly, the seed company has the imitial opportunity to avoid risk through careful handling. Inequality of opportunity to fimance risk comes from the nature of the use for which the goods are sold; in this case the purchaser typically uses then for one all-or-nothing investment in the crop, thus placing himself in the relatively worse position to finance a crop failure. ${ }^{12}$

105. A third instance may be personal injury loss and, perhaps in some consumer cases, economic loss. See note 82 supra.

106. See Q. Vandenberg \& Sons v. Siter, 204 Pa. Super. 392, 204 A.2d 494, 2 UCC REP. SERV. 383 (1964) (question of unreasonableness should go to jury).

107. Gore v. Ball, 279 N.C. 192, 182 S.E.2d 389 (1971) (pre-Code). The North Carolina Supreme Court distinguished the case in an unsatisfactory opinion, Billings v. Jos. Harris Co., 290 N.C. 502, 222 S.E.2d 695 (1976).

108. Dessert Seed Co. v. Drew Farmers Supply Co., 248 Ark. 858, 454 S.W.2d 307, 7 UCC REP. SERV. 995 (1970).

109. Klein v. Asgrow Seed Co., 246 Cal. App. 2d 87, 54 Cal. Rptr. 609, 3 UCC REP. SERV. 934 (3d Dist. 1966).

110. 248 Ark. 858, 454 S.W.2d 307, 7 UCC ReP. SERV. 995 (1970).

111. Id.

112. The farmer or grower is at least typically conceived as being in a poor position to finance the risk of crop failure. The difficulty of underwriting this type of risk also 


\section{Undiscoverable Defects: A Summary}

Cases considering the applicability of limitation of remedy where goods contain "undiscoverable defects" are one of the two types of situations to which section 2-719(2) has thus far been applied. Failure to appreciate Llewellyn's intended methodology, however, has led courts to give section 2-719(2) an unduly broad interpretation. The results contrast sharply to those which might be expected under a theoretically sound unconscionability analysis.

Nevertheless, these cases suggest an analytic process that allows thoughtful development of case law under section 2-719. This process mvolves three steps. First, the court must inform itself about the potential purposes that a given forn of limited remedy might serve in the type of transaction confronted. Courts have thus far proved deficient at this step; more is required than sinply reading the documentation of the transaction. Second, once these potential purposes are known, the court must consider whether one or more of them will be furthered by application of the limitation of remedy in the particular circumstances. That is, will application of the remedy further the purposes, or may the reinedy be said to have failed of its essential purpose under the given facts? Third, if application of the remedy is called for, does it work an unconscionable result? In part this last step will require consideration of the bargaining context, so that the court 1nay evaluate issues of "procedural" unconscionability. But insofar as the substantive operation of the clause is concerned, the court's ability to deal intelligently with the issue of unconscionability should be markedly inproved if it has carefully carried through its "purposive" evaluation of the clause and transaction at the outset.

II

\section{LIMITED REPAIR WARRANTIES}

\section{A. Introduction}

The analytic process proposed in the previous section may be tested by applying it to the second recurrent situation in which section 2-719(2) is presently utilized: the case of a limited repair warranty provision. Automobiles, nany other consumer products, and substantial numbers of commercial and industrial products are typically sold with such a "warranty." These provisions have a number of elements: first, a carefully delineated express warranty is made; second, all other

resulted in the long-time unavailability of crop insurance. Although the seller still stands in the position of financing downstream losses well in excess of profit on the individual transaction, the relative ability to finance loss is nonetheless changed from a $\mathrm{Wil}$ son-type setting. 
warranties, express or implied, are disclaimed; third, the remedy for breach of the express warranty is limited to a sole remedy of repair or replacement, at the seller's option; and fourth, the provision may additionally state that seller shall have no liability for consequential damages. When carefully drafted, such a provision accords with the freedom of contract that Article Two recognizes; indeed, specific Code authority may be cited for each element of the term. ${ }^{113}$ Nevertheless, such clauses have been subject to a variety of attacks. Putting aside issues of personal injury, ${ }^{114}$ the najor battles currently swirling around the limited repair warranty concern recoverability of economic loss: diminished value of the goods sold, consequential economic loss, or both. ${ }^{115}$

Attempts to recover such damages usually begin with an attack upon the validity of the limited repair warranty. Here, although the courts have not always done so, it is necessary to note the Code's distinction between disclamier of warranty and limitation of remedy. Disclaimer is governed most directly by section $2-316$, which restricts itself to establishing standards for effective disclaimer of implied warran-

113. Section 2-313 delimits the circumstances under which express warranties will arise; an express warranty may be disclaimed except "to the extent that such construction is unreasonable." UNIFORM COMMERCIAL CODE $\S 2-316(1)$. This limitation need not preclude the seller from giving a single carefully drawn warranty and excluding all other express warranties. The Code's implied warranties of merchantability (section 2 314) and fitness for a particular purpose (section 2-315) are both subject to disclaimer under section 2-316. Limitation of remedy to repair or replacement is specifically validated by section 2-719(1)(a), as is exclusion of consequential damages by section 2719(3). Freedom to limit remedy in the above manner is subject to two restrictions: an exclusive remedy may be avoided where it "fails of its essential purpose," and limitation of consequential damages is ineffective where "unconscionable."

This summary of potentially applicable Code sections is not exhaustive; under the Code's complex (perhaps overly so) theoretical structure, a simple application of this very common form of contractual provision may call for the application of a large number of Code provisions. See generally Weintraub, supra note 4 .

114. Most jurisdictions now impose liability upon a manufacturer for personal injury caused by its defective goods, without reference to any disclaimer of warranty or limitation of liability or, indeed, other "intricacies of the law of sales." See Greenman v. Yuba Power Prods., Inc., 59 Cal. 2d 57, 377 P.2d 897, 27 Cal. Rptr. 697 (1963); Annot., 13 A.L.R.3d 1049, 1057 (1967). See also Restatement (SECOND) of ToRTs $\S 402 \mathrm{~A}(1965)$ and accompanying commentary.

115. On the as yet ill-defined boundaries between tort and contract theories in this area, see Franklin, When Worlds Collide: Liability Theories and Disclaimers in Defective-Product Cases, 18 Stan. L. REv. 974 (1966); Shanker, Strict Tort Theory of Products Liability and the Uniform Commercial Code: A Commentary on Jurisprudential Eclipses, Pigeonholes and Communications Barriers, 17 W. RES. L. REV. 5 (1965); Speidel, Products Liability, Economic Loss and the UCC, 40 TenN. L. Rev. 309 (1973). Contpare Seely v. White Motor Co., 63 Cal. 2d 9, 403 P.2d 145, 45 Cal. Rptr. 17 (1965), with Santor v. A. \& M. Karagheusian, Inc., 44 N.J. 52, 207 A.2d 305 (1965), and Herbstman v. Eastman Kodak Co., 68 N.J. 1, 342 A.2d 181, 17 UCC REP. SERv. 39 (1975). 
ties. ${ }^{116}$ Although it does impose some minimal restrictions upon negation of express warranties, a carefully drawn limited repair warranty provision will have no difficulty complying with the section. ${ }^{117}$ In the face of the apparent validation of complying disclaimers by section 2-316, a few jurisdictions have extended tort liability to cover economic loss, ${ }^{118}$ and decisions elsewhere have voided disclaimers despite compliance with section 2-316. ${ }^{118}$ Some states have adopted nonuniform versions of section 2-316, prohibiting disclaimer of implied warranties in consumer transactions. ${ }^{120}$ And under the Magnuson-Moss Warranty -Federal Trade Commission Improvement Act, ${ }^{121}$ it will no longer be

116. UNIFORM COMMERCIAL CODE $\S 2-316(2)$ is most pertinent to disclaimers drafted for inclusion in form contracts:

[T]o exclude or modify the implied warranty of merchantability or any part of it the language must mention merchantability and in case of a writing must be conspicuous, and to exclude or modify any implied warranty of fitness the exclusion must be by a writing and conspicuous. Language to exclude all implied warranties of fitness is sufficient if it states, for example, that "There are no warranties which extend beyond the description on the face hereof."

117. By giving a narrow express warranty, and only disclaiming other express warranties, seller can defeat claims of repugnancy between express warranties and the disclaimer.

118. Cf. Santor v. A. \& M. Karagheusian, Inc., 44 N.J. 52, 207 A.2d 305 (1965); Cova v. Harley Davidson Motor Co., 26 Mich. App. 602, 182 N.W.2d 800 (1971), and cases cited therein at 810 n.34.

119. No attempt is made here to collect the voluminous case law on this issue. See generally WHITE \& SUMMERS, supra note 9, at 383-96. Analysis of the cases is complicated by the courts' tendency to disregard the Code's distinction between disclaimer and limitation of remedy, as well as by the overlap between tort theory, sometimes articulated as "warranty" liability, and traditional warranty theory.

120. The Massachusetts provision is typical and has served as a model elsewhere: $\S 2-316 \mathrm{~A}$. Limitation of Exclusion or Modification of Warranties.

The provisions of section 2-316 shall not apply to sales of consumer goods, services or both. Any language, oral or written, used by a seller or manufacturer of consumer goods and services, which attempts to exclude or modify any implied warranties of merchantability and fitness for a particular purpose or to exclude or modify the consumer's remedies for breach of those warranties, shall be unenforceable.

Any language, oral or written, used by a manufacturer of consumer goods, which attempts to limit or modify a consumer's remedies for breach of such manufacturer's express warranties, shall be unenforceable, unless such manufacturer maiutains facilities within the commonwealth sufficient to provide reasonable and expeditious performance of the warranty obligations. ment.

The provisions of this section may not be disclaimed or waived by agree-

Mass. ANN. Laws ch. 106, $\$ 2-316$ A (Supp. 1976).

121. Title I, "Consumer Product Warranties," 15 U.S.C. \$\$ 2301-12 (Supp. V, 1975), provides for minimum disclosure standards for written warranties of consumer products, requires warranties to be designated as either "full" warranties or "limited" warranties, and imposes minimal standards for "full" warranties. A warrantor extending a written warranty may not disclaim implied warranties, although, so long as only a limited warranty is given, the duration of implied warranties may be limited to the period of the express warranty. 15 U.S.C. $\$ \$ 2308,2304(a)^{4}(2)$ (Supp. V, 1975). All these consequences follow only if a "written warranty" (15 U.S.C. $\$$ 2301(6) (Supp. V, 1975 )) is given. The legislation does not require any supplier to warrant any product; 
possible for those who make certain types of express warranties to disclaim at the same time an implied warranty of merchantability.

Despite these inroads, in the vast majority of commercial transactions and in a substantial number of consumer transactions, it remains possible for sellers to disclaim implied warranty liability. Thus the pressure exerted by those seeking relief for their disappoimted economic expectations is shifted to the seller's attempted limitation of remedies for breach of the express warranty given.

As noted, the typical limited repair warranty embodies an exclusive remedy of repair or replacement and an exclusion of consequential damages. Section 2-719(1)(a) validates the former; ${ }^{122}$ section 2-719 (3) the latter, unless unconscionable. Sucli a "repair or replace" provision not only operates equitably but also mimimizes senseless economic waste. ${ }^{123}$ It assures that in the end the buyer will receive substantially what was bargained for-a functioning item meeting the

competitive pressures are relied upon to indnce sellers to give some written warranty, thus subjecting themselves to the Act's further requirements.

122. UNIFORM COMMERCIAL CODE § 2-719:

Contractual Modification or Limitation of Remedy

(1) Subject to the provisions of subsections (2) and (3) of this section

and of the preceding section on liquidation and limitation of damages,

(a) the agreement may provide for remedies in addition to or in substitution for those provided in this Article and may limit or alter the measure of damages recoverable under this Article, as by limiting the buyer's remedies to return of the goods and repayment of the price or to repair and replacement of non-conforming goods or parts; and

(b) resort to a remedy as provided is optional unless the remedy is expresssly agreed to be exclusive, in which case it is the sole remedy.

123. A good example of such "repair or replace" clauses is found in Lankford v. Rogers Ford Sales, 478 S.W.2d 248, 250, 10 UCC REP. SERv. 777, 778 (Tex. Civ. App. 1972):

\section{Basic Warranty}

"Ford Motor Company warrants to the owner each part of this vehicle to be free under normal use and service from defects in material and workmanship for a period of 24 months from the date of original retail delivery or first use, or until it has been driven for 24,000 miles, whichever comes first. . . .

"All the warranties shall be fulfilled by the Selling Dealer (or if the owner is traveling or has become a resident of a different locality, by any authorized Ford or Lincoln-Mercury dealer) replacing with a genuine new Ford or Ford Authorized Reconditioned part, or repairing at his place of business, free of charge including related labor, any such defective part. . . .

"The warranties herein are expressly IN LIEU of any other express or implied warranty, including any implied WARRANTY of MERCHANTABILITY or FITNESS, and of any other obligation on the part of the Company or the Selling Dealer."

This provision accomplishes two distinct purposes: it establishes the characteristics of the good sold (by its disclaimer of warranties in the final paragraph, and the substitution of the express warranty iu the first paragraph); and it states the manner in which it will be assured that the buyer receives goods with thcse characteristics (by the repair obligation set forth in the secoud paragraph). 
contract description. ${ }^{124}$ Yet although holding the seller to this substantial performance standard, it does not impose an unrealistic standard of perfection. ${ }^{125}$

For exainple, consider a consumer who purchases a new refrigerator. On the third day of operation a defect in the compressor becomes apparent. This defect absolutely prevents the refrigerator from operating; that is, it very substantially impairs the value of the refrigerator to the buyer. ${ }^{126}$ Accordingly, if the other conditions of section 2-608 are met, the buyer will normally be entitled to revoke the acceptance and tender back the refrigerator. ${ }^{127}$ Assuming that the seller later fixes the defective coil, the refrigerator, which sells now as a "used" refrigerator of "unknown lineage," 128 will sell at a substantially discounted price. This discount will reflect in part societal antipathy to "used goods" and in part a rational discounting of the price to reflect unknown potential defects, including those that may have been acquired during the first ownership period. ${ }^{129}$ In any case, a "loss" will be imposed on the seller here that inay be avoided if the seller has an option to repair the goods. ${ }^{130}$ The "repair or replace" warranty nay thus be

124. That is, if he wished to buy functioning item $X$, the buyer will eventually have functioning item $X$. This proposition does not take account of "indirect" damages, either incidental or consequential. A consideration of the potential role of the limited "repair or replace" warranty in precluding such damages is central to a full consideration of section 2-719(2)'s concept of failure of essential purpose; discussion, however, is deferred for the present.

125. This statement is not quite accurate. As to accepted goods the seller is held only to a standard of substantial performance, because "revocation of acceptance" will be allowed only if there is a "non-conformity" that "substantially impairs its value to [the buyer]." UNIFORM COMMERCIAL CODE $\$ 2-608$. But the "repair or replace" limitation does serve to mimimize economic loss, while still imposing a substantial performance standard.

126. This conclusion follows whether one measures the remaining "value" of the refrigerator by its resale value (which we may reasonably suppose to be poor) or by its cost of repair, or by its current use value (that is, as a storage cabinet).

127. UNIFORM COMMERCIAL CODE $\$ 2-608$ :

Revocation of Acceptance in Whole or in Part.

(1) The buyer may revoke his acceptance of a lot or commercial unit whose non-conformity substantially impairs its value to him if he has accepted it

(a) on the reasonable assumption that its non-conformity would be cured and it has not been seasonably cured; or

(b) without discovery of such non-conformity if his acceptance was reasonably induced either by the difficulty of discovery before acceptance or by the seller's assurances.

128. Cf. Zabriskie Chevrolet, Inc. v. Smith, 99 N.J. Super. 441, 240 A.2d 195, 5 UCC REP. SERV. 30 (1968) (lineage of transmission "unknown").

129. See generally id.

130. The "loss" component reflecting societal antipathy to "used goods" is avoided in this instance simply by refusing to recognize it. The loss component due to rational discounting to reflect potential defects is eliminated by keeping the transaction between the two original parties. If such defects materialize, they will (a) stem from buyer's use, so that he is not entitled to compensation, or (b) flow from additional breaches 
portrayed as a fair balancing of the interests of the two parties. Indeed, to a limited extent, the Code requires that a buyer allow a seller such opportunities: this is the precise aim of the Code's "cure" provision, section 2-508. ${ }^{131}$ The limited repair warranty, therefore, represents a contractual extension of the cure concept, and similar policies of "substantial performance" appear to support it.

This rosy picture of the limited repair warranty, however, rests upon at least three assumptions: that the warrantor will diligently make repairs, that such repairs will imdeed "cure" the defects, and that consequential loss in the interim will be negligible. So long as these assumptions hold true, the limited remedy appears to operate fairly and, as noted above, will usually withstand contentions of "unconscionability." But when one of these assumptions proves false in a particular case, the purchaser inay find that the substantial benefit of the bargain has been lost. The language of the Official Comment to section 2-719 squarely supports this proposition:

[U]nder subsection (2), where an apparently fair and reasonable clause because of circumstances fails in its purpose or operates to deprive either party of the substantial value of the bargam, it must give way to the general remedy provisions of this Article. ${ }^{132}$

With increasing frequency purchasers are raising section 2-719(2) contentions in such circumstances, and courts have displayed confusion in dealing with the arguments.

Under the analysis previously proposed, the first step is to determine the purposes served by a linited remedy. As in the case of "undiscoverable defects," however, courts have been slow to recognize the need for such analysis. Instead, while perhaps perceiving implicitly the nature of the transaction and therefore the "essential purpose" of the limited remedy, soine courts have chosen to focus on such inorally laden issues as the character of defendant's conduct. Such einphasis may give rise to a rule of decision that is at the same time too narrow and too broad: too narrow because contract liability is often strict liability, with the consequence that a limited remedy inay fail of its

of warranty, and seller must again repair. On the "lemon" problem and successive repairs, see text accompanying note 144 infra.

131. UNIFORM COMMERCIAL CODE $\$ 2-508$ :

Cure by Seller of Improper Tender or Delivery; Replacement

(1) Where any tender or delivery by the seller is rejected because nonconforming and the time for performance has not yet expired, the seller may seasonably notify the buyer of his intention to cure and may then within the contract time make a conforming delivery.

(2) Where the buyer rejects a non-conforming tender which the seller had reasonable grounds to believe would be acceptable with or without money allowance the seller may if he seasonably notifies the buyer have a further reasonable time to substitute a conforming tender.

132. Uniform Commercial Code $\$ 2-719$, Comment 1 . 
essential purpose despite the innocence of the warrantor; too broad because, conversely, the "bad" character of a contractant is not a reliable guide for the imposition of liability in circumstances in which the parties' agreeinent may narrowly define the contractant's obligation. A brief examination of the cases will demonstrate both propositions.

\section{B. Case Law: A Preliminary View}

Adams v. J.I. Case Co. ${ }^{133}$ appears to be the first case dealing with the application of section 2-719(2) to situations involving limited repair warranties. The opinion illustrates the severe difficulty many courts experience in dealing with the Code's complex warranty/ disclaimer/limitation of remedy provisions, all of which are brought into play by a limited repair warranty. An extended discussion of the case may thus serve as an overview of the range of problems to be anticipated in the area, as courts unfamiliar with the Code's structure struggle to establish the relationship between section 2-719(2) and the other Article Two warranty/disclaimer/limitation of remedy provisions.

Plamtiff Adams purchased a $\$ 14,000$ crawler-loader tractor for use in his bulldozing business. Because of a defective radiator, it was subject to chronic overheating that made it inoperable in weather warmer than $75^{\circ}$. Moreover, the bucket's hydraulic system was defective, so that the bucket would not remain raised. Plaintiff advised both the manufacturer and the dealer of these defects. Rather than fixing thein within a reasonable time (allegedly a week), however, the dealer allowed the inachine to remain in the repair shop, often receiving no attention, for nearly 3 months. Adams subsequently sued the manufacturer and the dealer, seeking to recover repair costs in excess of $\$ 500$ and lost earnings in excess of $\$ 9,000$. Defendants moved to dismiss the complaint in part on the theory that the limited warranty provision barred the action. The tractor had been sold with a written warranty containing a promise to repair or replace defective parts for 12 months, disclaiming other warranties and excluding consequential damages.

The court correctly identified the crux of plaintiff's complaint:

[D]efendants were under a duty to make timely repairs called for by their warranty but the defendants took an inordinate amount of time in making the repairs, in that they were wilfully dilatory or were careless and negligent in their work of compliance, with the result that plaintiff has suffered direct and consequential damage. ${ }^{134}$

Such a complaint thus raises two issues: the proper measure of dainages "directly" caused by breach of the promise to repair; and the

133. 125 Ill. App. 2d 388, 261 N.E.2d 1, 7 UCC REP. SERV. 1270 (1970).

134. Id. at 400,261 N.E.2d at 6, 7 UCC REP. SERv. at 1274-75. 
effect of the contractual exclusion of consequential damages on plaintiff's ability to recover for breach of the promise to repair.

The court properly construed the promise to repair, stating no time for performance, as a promise to repair within a reasonable time ${ }^{135}$ and found a breach for failure to do so. That a buyer has no remedy for defective goods other than to request repair does not reasonably mean that the buyer has no remedy if the seller fails to repair. ${ }^{136}$ Once having determined that the repair promise was not illusory, the court easily found that the costs of "covering" by seeking repairs elsewhere was a reasonable measure of direct dainages. ${ }^{137}$

The propriety of awarding consequential damages, which forms the principal focus of the opinion in J.I. Case, presents a more elusive problem, two aspects of which may be identified. First, in the absence of contractual limitation, would the damages sought be properly recoverable: were the requirements of foreseeability, certainty, and mitigation met? ${ }^{138}$ Second, if otherwise properly recoverable, were they nevertheless excluded by the contractual provision? Although the court dealt with both aspects, discussion here is limited to the latter. ${ }^{130}$

Although the court identified an express warranty, it did not directly pose the question whether consequential damages were recoverable for its breach. Rather, it assumed that the exclusion of consequential damages applied not only to damages flowing from breach of the obligation to deliver nondefective goods, but equally to breach of the promise to repair them. Yet this issue is precisely the one that the court ought to have analyzed and resolved rather than assumed

135. UNIFORM COMMERCIAL CODE \$ 2-309(1): "The time for shipment or delivery or any other action under a contract if not provided in this Article or agreed upon shall be a reasonable time."

136. See Koehring Co. v. A.P.I., Inc., 369 F. Supp. 882, 890, 14 UCC REP. SERv. 368, 378 (E.D. Mich. 1974):

In a sense, there are two breaches of the contract; the first being the failure to deliver goods conforming to the express warranty, and the second being the failure to correct the nonconformity as was promised in the party's (sic) agreement.

137. Although the court did not apply the normal measure of damages for breach of warranty, UNIFORM COMMERCIAL CODE $\$ 2-714(2)$, so long as repair is a reasonable remedy and does not accentuate plaintiff's damages, section 2-715(1) authorizes a court to use such a measnre. Whether defendant can restrict plaintiff to the repair cost is a different matter. Cf. Ford Motor Co. v. Gunn, 123 Ga. App. 550, 181 S.E.2d 694, 8 UCC REP. SERV. 1180 (1971).

138. See generally WhITE \& SUMMERs, supra note 9 , at 306-25; D. DoBBS, supra note 8 , at $148-58,798-817$.

139. Although these aspects are analytically separable, one suspects that courts addressing themselves explicitly to the validity of a limitation clause are also moved by considerations of certainty, mitigation, and foreseeability, even though not addressed. See V-M Corp. v. Bernard Distrib. Co., 447 F.2d 864, 9 UCC REP. SERv. 670 (7th Cir. 1971), discussed at text accompanying note 161 infra. 
away. Unsatisfied with the result that its nonanalysis yielded, the court then proceeded by a lengthy and highly fictional process to "create" an implied warranty, for the breach of which consequential damages may be recovered. Specifically, it reasoned that such a warranty arose from a "course of dealing or usage of trade"140 and that the contractual disclaimer of all implied warranties was not effective because "defendants' repudiation for failure to reasonably comply avoids the exclusion." 141 Without further discussion it then assumed that consequential damages were recoverable for breach of the implied warranty.

In short, despite a valid exclusion of implied warranties, ${ }^{142}$ the court invoked the fiction of implied warranty to allow a suit for the consequential damages flowing from breach of the express warranty. Since no basis existed for the implication other than the existence of the express warranty, the court achieved by a circuitous and fictional process the exact result it regarded as precluded by the limitation of consequential damages. In devoting its attention to the irrelevant question whether it may create such an implied warranty, the court provided very little analysis of why allowing consequential damages was appropriate. And it lends support to the false proposition that "failure of purpose" of a limited remedy under section 2-719(2) not only reinstates all appropriate Code remedies, but also may result in the creation of new warranties.

Several hypotheses may be offered to explain the court's difficulty in squarely addressing itself to the issue before it. First, prior to the Code's adoption, when the courts lacked explicit authority for providing relief from contracts embodying unconscionable provisions or provisions that "failed of their purpose," tortured construction was the principal and accepted available tool. And today, despite the forthright avenues provided by the Code, some courts apparently feel more secure in old and devious paths. J.I. Case may be partially explaimed on this ground.

Second, the complexity both of the Code's scheme for disclaimer of warranty and limitation of remedy, and of the typical limited repair warranty, invites confusion. Not surprisingly, courts often have trouble

140. 125 IIl. App. 2d at 403-04, 261 N.E.2d at 8, 7 UCC ReP. Serv. at 1277. The court cited section 2-314(3).

141. 125 IIl. App. 2 d at $403-04,261$ N.E.2d at 8, 7 UCC REP. SERv. at 1277. In fact, the disclaimer was of questionable efficacy. See note 142 infra.

142. More correctly, the provision provided merely for a disclaimer of warranty, which the court regarded as effectively disclaiming implied warranties. As described by the court, 125 III. App. 2d at 398-99, 261 N.E.2d at 6-7, UCC REP. SERv. at 1274, the disclaimer fails to mention "merchantability" and was therefore ineffective to disclaim a section 2-314 implied warranty of merchantability. UNIFORM COMMERCIAL CODE § 2-316(2)(a). This failure, however, should not have been material. As noted in the text, a source of liability was already present, and the limitation of remedy was not drawn to apply only to a given source of liability. 
separating a limited repair warranty clause into the discrete components that the Code recognizes. J.I. Case demonstrates this failure on two planes. Initially, the court assumed that the exclusion of consequential damages (limitation of remedy) also operated to negate the express warranty as a basis for liability (thus giving it the effect of a disclaimer of warranty). Then, finding that the limited remedy had failed of its essential purpose, the court did not confine itself to invalidating the limitation of remedy, but invalidated the disclaimer of warranty as well. In J.I. Case, since the implied warranty created was only equivalent to the express warranty that the seller had given, the court reached a just result. But acceptance of the court's theory would also allow "revival" of effectively disclaimed warranties of merchantability or fitness, substantially remaking the parties' bargain. This result would give section 2-719(2) a punitive character not only at odds with normal contract principles, but also without support in either Code structure or the language of section 2-719(2) itself.

Third, J.I. Case typifies much post-Code case law in its talismanic resort to Code language. This defect, particularly evident in the court's "implied warranty" argument, also surfaced when the court turned to consider section 2-719(2):

The complaint alleges facts that would constitute a repudiation by the defendants of their obligations under the warranty, that repudiation consisting in their wilful failure or their careless and negligent compliance. It should be obvious that they cannot at once repudiate their obligation under the warranty and assert its provisions beneficial to them. Thus the allegations of Count $\Pi$ of plaintiff's complaint invoke other provisions of the Uniform Commercial Code. Section 2-719(2) provides:

'Where circumstances cause an exclusive or limited remedy to fail of its essential purpose, remedy may be had as provided in this Act.'

Failure of the exclusive remedy provided in the warranty is readily found in the allegation that defendants were wilfully dilatory or careless and negligent in complying with their obligations under the warranty. ${ }^{143}$

But to state that it is "obvious" that the purchasers could not "at once repudiate their obligation under the warranty and assert its provisions beneficial to them" begs the very inquiry that the court should have been making. Neither the "essential purpose" of the exlusive remedy nor, a fortiori, the "failure" of that purpose was a self-evident inatter; none theless, the court easily concluded that repudiation of the repair obligation caused the repair obligation to fail of its purpose. Thus the court

143. 125 Ill. App. $2 d$ at $402-03,261$ N.E.2d at 7-8, 7 UCC Rep. SERV. at 1276. 
allowed resort to all remedies, without ever having identified the purpose of the limited remedy or why it had failed. If consequential dainages are recoverable because of a "failure of essential purpose" of the remedy, this conclusion too must be explamed, and not simply asserted.

\section{Lemons and Chiselers-Inability to Perform and Refusal to Reform}

Whatever the shortcomings of its reasoning, the decision in J.I. Case gave currency to two propositions: (1) that a limited repair-orreplace remedy "fails of its essential purpose" when there is a "repudiation" of the repair obligation or when the warrantor is "wilfully dilatory or careless and negligent in complying" with the warranty obligation; and (2) that when a remedy so fails of its purpose, the aggrieved party may recover consequential damages, despite the presence of an additional clause in the contract excluding such damages. The discussion now turns to the development and elaboration of these propositions in subsequent case law, considering first the issue of when a limited remedy fails of its purpose.

Our initially favorable description of the limited repair warranty assumed that the warrantor would be willing and able to repair. If the assumption is maccurate the purchaser may be saddled with goods of substantially less value than defect-free goods. The purchaser would likely describe either a refusal or an inability to repair as situations in which the limited remedy "operates to deprive either party of the substantial value of the bargain."144 But not all courts have agreed that the two cases should be created the same. One view maintains that a failure of essential purpose results only when a warrantor's failure to repair is "willfully dilatory or careless and negligent."145 Another view holds that a failure of purpose occurs "whenever the warrantor fails to correct the defect within a reasonable time."146

As noted, J.I. Case may be viewed as simply enforcing a limited remedy, rather than involving the failure of a reinedy. Where the warrantor has refused to attempt repair, or has abandoned repairs after an mitial period of compliance, courts have readily agreed with J.I.Case that the limited repair warranty fails of its purpose. The majority of such cases, however, have contributed little analysis of their own, usually contenting themselves with a citation to J.I. Case and its pro-

144. UNIFORM COMMERCIAL CODE $\$ 2-719$, Comment 1, quoted at note 10 supra.

145. Potomac Elec. Power Co. v. Westinghouse Elec. Corp., 385 F. Supp. 572, 16 UCC REP. SERV. 360 (D.D.C. 1974), rev'd mem. and remanded on procedural grounds (see note 167 infra), 527 F.2d 853 (D.C. Cir. 1975); Lankford v. Rogers Ford Sales, 478 S.W.2d 248, 10 UCC Rep. Serv. 777 (Tex. Civ. App. 1972).

146. Beal v. General Motors Corp., 354 F. Supp. 423, 12 UCC Rep. SERv. 105 (D. Del. 1973). 
geny. Recurrently, these cases seize upon the formulation that a limited repair warranty fails of its essential purpose where the warrantor is "wilfully dilatory, careless or negligent." It is true that this may be one instance in which such a remedy fails. But is it the only instance? Suppose that the warrantor struggles diligently, but without effect, to repair. Such a case may not be described as involving "wilfully dilatory, careless or negligent" repair. The purchaser, however, may nevertheless lose the substantial value of the bargain. May the purchaser avoid this result by invoking section 2-719(2)?

The issue arose in Lankford $v$. Rogers Ford Sales, ${ }^{147}$ where the plaintiff purchased a new Ford Thunderbird, only to find himself plagued by a series of exasperating defects requiring 45 days in the shop during the first 18 months of operation. The plaintiff did not seek to revoke his acceptance of the vehicle, but did seek damages. Affirming the lower court's summary judgment for the defendant, the court of appeals held that the defendant had properly limited its liability to repair and replacement and that this limited remedy did not fail of its essential purpose even if the vehicle was still not of "merchantable quality":

[I]t is important to note that the plaintiff admits that on each and every occasion that a defect has occurred, the same has been repaired by a Ford dealer. Thus, there is no ... allegation of dilatory, careless or negligent compliance with the terms of the limited warranty. In the absence of such circumstances, we must conclude, as a matter of law, that the limited warranty has not failed of its essential purpose. ${ }^{148}$

Lankford thus strongly suggests the acceptance of a negative inference from J.I. Case: a limited repair warranty fails of its essential purpose if, but only if, the warrantor is "dilatory, careless or negligent" in complying with the repair obligation.

Two points of the plaintiff's case in Lankford deserve einphasis. First, plaintiff alleged neither unwillingness nor inability to perforn. Although the language quoted directs its attention to defendant's willingness to repair, plaintiff's admission that repairs were in fact effected in each imstance undercuts the application of the case to any situation involving a wholly willing warrantor who is unable, despite diligent efforts, to effect "repair." Second, the theory of the plaintiff's case appears to have been that the limited written warranty failed of its essential purpose and, therefore, that he should be entitled to rely on implied warranties of fitness and merchantability for relief. ${ }^{149}$

147. 478 S.W.2d 248, 10 UCC REp. SERv. 777 (Tex. Civ. App. 1972).

148. Id. at 251, 10 UCC REP. SERv. at 780 (citing J.I. Case).

149. Id. at 249, 10 UCC REP. SERV, at 778. 
These warranties had been effectively disclaimed, but such confused discussions as appear in J.I. Case invited the argument that the failure of a limited remedy not only allows resort to all Code remedies, but also resurrects disclaimed warranties. By articulating his case in this manner, plaintiff may have contributed to its rejection.

Lankford is an excellent backdrop for an attempt to isolate one of the functions served by the limited repair warranty. The case involved a typical warranty that established two separate matters: the characteristics of the goods sold and the manner in which a buyer is assured of receiving such goods. ${ }^{150}$ The court correctly rejected the argument that since the limited remedy failed of its purpose, the buyer was entitled to insist on a different warranty (merchantability or fitness) in place of that given as part of the original warranty (no defects for 24,000 miles). At the same time, however, the court wrongly accepted the proposition that by accepting a limited remedy the buyer agreed to a lesser "ultimate" performance standard.

The limited remedy clause here precluded the buyer from immediately asserting a damage claim when a defect was first discovered; similarly, it precluded the buyer from revoking his acceptance of the goods even if the defect had substantially impaired their value. But the court should not have construed the clause, which addressed itself to the issue of how a given product standard shall be attained, as changing what that standard should have been. ${ }^{151}$ In fact, the gist of plaintiff's complaint in Lankford was not that the vehicle was "unmerchantable," but that it could not reasonably be described as a vehicle free of defects for 24,000 miles. That the answer to both questions (that is, whether this vehicle is merchantable, and whether this vehicle is properly described by a warranty of freedoun from defects for 24,000 miles) may be the same in many instances should not obscure the fact that a different question is being asked. Rather than having phrased his argument in terms of a warranty of merchantability, the buyer might

150. For the full text of the warranty, see note 123 supra.

151. In the case of "standard" goods, where it is contemplated that any individual item, while not necessarily perfect, can be brought to standard through minimal repair and adjustment, any other construction would be "surprising" and hence potentially subject to an unconscionability attack. Failure of purpose doctrine and unconscionability thus work together to insure a minimal content to the bargain: a narrow construction results in failure of the clause's purpose; a broad construction results in its unconscionability. The key to this analysis is the underlying "type-transaction." As we move away from standardized goods, a construction of the remedy clause that alters the endproduct standard becomes less surprising. Cf. U.S. Fibres, Inc. v. Proctor \& Schwartz, Inc., 509 F.2d 1043, 16 UCC REP. SERv. 1 (6th Cir. 1975), aff'g 358 F. Supp. 449, 13 UCC ReP. SERv. 254 (E.D. Mich. 1972); Potomac Elec. Power Co. v. Westinghouse Elec. Corp., 385 F. Supp. 572, 16 UCC REP. SERv. 360 (D.D.C. 1974); Raybond Elecs. v. Glen-Mar Door Mfg. Co., 22 Ariz. App. 409, 528 P.2d 160, 16 UCC REP. SERV. 121 (1974). 
properly have argued that the agreed remedy, repair, had failed to provide what the parties had agreed upon as the final product: a vehicle that may be described, substantially, as free from defects during 24,000 miles. Even a vehicle with a bad transmission might be so described, if the transmission were promptly repaired. But Lankford could have asserted that a vehicle with defects great or small cannot fairly be described as such, even if all defects are repaired, if effecting the repairs prevents normal operation during a significant portion of the 24month period.

This understanding of the "essential purpose" of a limited repair warranty "does no more than invoke intelligent construction of the contract clause, so that it would be applied to those circumstances realistically contemplated by the parties."152 Moreover, it is consistent with the notion that "the subsection is not concerned with arrangements which were oppressive at their inception, but rather with the application of an agreement to novel circumstances not contemplated by the parties."153 Thus, so long as the buyer has the use of a substantially defect-free vehicle, the clause should be given effect; in many circumstances the repair remedy can "deliver" such a vehicle. But when it cannot, it fails of its purpose; in these circumstances it must give way to the contract's fundamental performance standard: the warranty. ${ }^{154}$ Whether the repair remedy fails of its purpose because the warrantor repudiates the repair obligation, or is not diligent, or is diligent but unable to repair the defect, or is diligent and able to repair the defect but there is an unceasing flow of defects, it is not determinative. For in each instance the buyer is deprived under the circumstances of the substantial value of the bargain. To uphold the limitation of remedy in such a case would alter the performance standard; thus the conflict between the performance standard and the agreed means of achieving it becomes irreconcilable. Either the performance standard or the

152. NEW York STudy, supra note 9, at 584 (statement of Professor John Honnold).

153. Id.

154. This theory is similar to the English doctrine of fundamental breach. See Meyer, Contracts of Adhesion and the Doctrine of Fundamental Breach, 50 VA. L. REv. 1178 (1964). So long as the limited remedy is given this narrow construction, which views it as a means to an end, it will fail of its essential pnrpose when it cannot produce the substantial value of the "end bargain." This result may not be avoided simply by interpreting the limitation of remedy as "an end in itself"; where the goods sold are standard items, such a construction would be "surprising." Although this latter construction shifts the focus of attack from "failure of purpose" to "unconscionability," from either perspective the clanse should be avoided. Cf. Ellinghaus, supra note 11, at 800 03. Where, however, the type of transaction is different, it may be commercially reasonable to view a limitation to repair as an "end in itself." See text accompanying note 159 infra. See also note 151 supra. 
limitation of remedy must be abandoned: section 2-719(2) sanctions the latter course.

Fortunately, more recent cases have clearly identified this issue. As a result there is some reason to hope that Lankford will be consigned to a distinct minority position and that courts will properly address the purpose of the remedy, and not simply the character of the warrantor's conduct.

A forthright opinion appears in Beal v. General Motors Corp. ${ }^{165}$ Plaintiff Beal purchased a heavy duty GMC diesel tractor. A "standard" 24,000-mile or 24-inonth warranty against defective parts and workmanship was given, limiting the remedy to repair or replacement. Plaintiff alleged that "General Motors was unable or unwilling to repair or replace the offending parts in such a way as to make the vehicle operable," 156 and he sought recovery of lost profits flowing from his mability to use the tractor in his busimess. In holding that the limited remedy "failed of its essential purpose" and that defendant's motion to strike allegations supporting the claim for consequential damages should therefore be denied, the court stated:

The purpose of an exclusive remedy of replacement or repair of defective parts, whose presence constitute [sic] a breach of an express warranty, is to give the seller an opportunity to make the goods conforming while limiting the risks to which he is subject by excluding direct and consequential damages that might otherwise arise. From the point of view of the buyer the purpose of the exclusive remedy is to give him goods that conform to the contract within a reasonable time after a defective part is discovered. When the warrantor fails to correct the defect as promised within a reasonable time he is liable for a breach of that warranty. . . . The limited, exclusive remedy fails of its purpose and is thus avoided under $\$ 2-719$ (2), whenever the warrantor fails to correct the defect within a reasonable time. ${ }^{187}$

Several other cases, all arising on roughly similar facts, are in accord with Beal's correct einphasis upon the result obtained, rather than the character of the warrantor's behavior. ${ }^{168}$

\section{Essential Purpose and the "Type-Transaction"}

When under the particular circumstances of a case the limited remedy may no longer be applied to further its purpose, it may be

155. 354 F. Supp. 423, 12 UCC REP. SERV. 105 (D. Del. 1973).

156. Id. at 425,12 UCC REP. SERV. at 107.

157. Id. at 426, 12 UCC REP. SERv, at 109.

158. See, e.g., Ford Motor Co. v. Gunn, 123 Ga. App. 2d 550, 181 S.E.2d 694, 8 UCC REP. SERv. 1180 (1971); Eckstein v. Cummins, 41 Ohio App. 2d 1, 321 N.E.2d 897, 16 UCC Rep. SeRv. 373 (1974); Moore v. Howard Pontiac-American, Inc., 492 S.W.2d 227, 12 UCC ReP. SERv. 676 (Tenn. App. 1972). 
described as having failed of its essential purpose. In the "type-transaction" examined thus far, this failure occurs whenever repair is unable to produce a functioning unit of the standard quality within a reasonable period of time. ${ }^{159}$ Certainly, failure of essential purpose will be the case when the warrantor does not even try to comply. Since, however, it inay equally be the case despite prodigious efforts by the warrantor, a rule directed only to the character of the defendant's conduct is too narrow.

If the only essential purpose of limited repair warranties were restriction of the means by which a given warranty standard could be obtained, the application of section 2-719(2) would be simplified. But there are potentially as many different essential purposes for such remedies as there are different "type-transactions." Courts, which are hardly oblivious to differences im business settimgs, have implicitly recognized this proposition and have been influenced by it. ${ }^{160}$ The misplaced focus of inuch of the early case law on the character of the defendant's conduct, however, served to obscure this point and to divert the court's attention from providing a rationale for their decisions grounded squarely in an analysis of the "type-transaction."

An excellent illustration is provided by $V-M$ Corp. v. Bernard Distributing Co. ${ }^{101}$ For over 10 years Bernard had distributed V-M's tape recorders, record players, and other electronic equipinent. In 1964 V-M introduced transistorized components in the manufacture of its products, with substantial changes in the electronic design of many of its products. An apparent decline in product quality and reliability followed: the number of units returned to Bernard and dealers for credit or warranty repairs soared, and denand for V-M products declined. The distributorship, which was renewable annually, was allowed to lapse on December 31,1965, in the midst of the dispute. At that time Bernard was indebted to V-M in excess of $\$ 50,000$. V-M eventually requested the return of all V-M products, credited Bernard for this material, and sued for the balance. Bernard appealed the disinissal of its counterlaims for distributor profits and extraordinary expenses, which the trial court viewed as barred by provisions of the distributorship agreement. The first of these provisions extended an express war-

159. As suggested earlier, any other construction might run afoul of the Code's unconscionability provision in this type-transaction. What exactly delineates "this typetransaction" is discussed further in the text accompanying note 165 infra.

160. The situation with which courts have most dexterously dealt involves autonnbiles, because automobiles comprise an instance of the broader type-transaction most accessible to judges in our society. The intricacies of the wool trade may require illumination; the intricacies of car repairs are known to all. Cf. Behaviorism and UCC, supra note 14 , at $289-93$.

161. 447 F.2d 864, 9 UCC REP. SERv. 670 (7th Cir. 1971). 
ranty against defective parts and workmanship, disclaimed other warranties, and extended a promise to repair or replace. The second excluded consequential damages and limited recovery to the selling price of the items involved. The third barred claims by either party seeking compensation for investment, loss of profits, or the like in the event of termination of the distributorship.

Although noting that "V-M did not fail to meet the obligations under [the limited repair warranty], so that it did not deprive Bernard of the benefits of the limited warranty provisions," 182 the court did not rest its decision on the character of defendant's conduct alone:

Moreover, we are not persuaded that $\S 2-719(2)$ otherwise requires the negation of the specific limitations of the contract. Section 2-719 was intended to encourage and facilitate consensual allocations of risks associated with the sale of goods. This is particularly true where commercial, rather than consumer sales are involved. Even where the defects of the goods cause substantial difficulties to those involved in wholesale and retail distribution, § 2-719(2) need not automatically require disregard of the particular limitations upon liability specified by the contracting parties. Here we cannot say that the defects in the quality of V-M's goods caused a failure of consideration for the distributorship agreement which would justify altering the particular allocation of these costs by making the manufacturer the insurer of distributor profits and extraordinary expenses. We see nothing in this record to justify protection of the distributor's profits or expenditures at the expense of the manufacturers. ${ }^{103}$

Thus the court interpreted the limited remedy provision to be a risk-shifting device similar to a bare exclusion of consequential damages. The promise to repair or replace, seemingly also applicable to the dispute, was ignored as mere surplusage. Obviously, the court understood the repair or replace clause as applicable only to the problem of defective parts, which the distributor inust replace for the end purchaser. The clause normally provides an agreed basis for the distributor to pass this replacement expense back to the manufacturer, but it has no ready application to solving problems involving distributor terminations and thus correctly was not allowed to upset the more directly applicable provisions bearing on risk allocation. Such understanding is possible only from a thorough analysis of the "essential nature" of this "type-transaction." The court properly focused upon the matter of commercial context and not upon the character of defendant's conduct or even the exact variations in the phraseology of the limited remedy clause. Sucli an approach is essential to the development of an appro-

162. Id. at 868-69, 9 UCC REP. SERV. at 675 .

163. Id. at 869, 9 UCC REP. SERV. at 675. 
priate sense of the application of section 2-719(2). The more explicit a court is in deriving its judgment from its understanding of the nature of the type of transaction, and in so doing ignoring equitable-sounding but eventually fruitless distinctions, the more likely is the attainment of an intelligible, predictable case law.

As Bernard imdicates, there is a gross difference in context between sale of a standardized item for use and sale of the same items to a distributorship. Where the difference is less extreme, more difficulty may be expected in discerning and articulatimg distinctions that are present. Thus the danger is increased that a court will either misperceive a transaction or, though perceiving it correctly, articulate its decision on a false basis that prepares the ground for later error by a credulous court or attorney. ${ }^{184}$

We may improve our understanding of the "type-transaction" involved in J.I. Case by contrasting it with a set of cases involving several parallel facts in which the limited repair warranty has been given effect. Sometimes an argument of "failure of purpose" has been made and failed; sometimes that issue has never been raised. Whether or not the argument has been raised, the cases present edifying fact situations for comparison.

Avenell $v$. Westinghouse Electric Corp. ${ }^{185}$ arose out of the sale to Toledo Edison Company of a Westinghouse turbine generator. The contract included an express 1-year parts-and-workmanship warranty, a promise to repair, and an exclusion of consequential damages. The turbine blades failed, requiring shutdown of the unit. Although Westinghouse replaced the blades, Toledo suffered an alleged $\$ 185,000$ of consequential damages in the interim. ${ }^{168}$ Avenell appealed from a summary judgment in favor of Westinghouse, arguing that the contract's disclaimer and himitation provisions were ineffective because inconspicuous, and that Westinghouse was strictly liable in tort for the consequential loss. Since neither of these arguments is very persuasive, one wonders why the plaintiff did not also argue that the himited remedy had failed of its essential purpose. The most plausible reason is that at the time that suit was filed very little case law under section 2-719(2) existed. In a similar case, however, Potomac Electric

164. See, e.g., Earl M. Jorgensen Co. v. Mark Constr., Inc., 540 P.2d 978, 17 UCC REP. SERV. 1126 (Hawaii 1975), discussed at note 187 infra.

165. 41 Ohio App. 150, 324 N.E.2d 583, 16 UCC Rep. SERv. 671 (Ct. App. 1974).

166. These damages stemmed from three sources: (1) additional generating costs incurred to maintain normal ontput (presumably, "additional" to the costs that would have been incurred in operating the defective generator); (2) loss of demand charges for short-term energy to other utility companies; and (3) loss of sales to other utilities under contract. Id. at 317, 324 N.E.2d at 585, 16 UCC REP. SERv. at 673 . Avenell, plaintiff in the case, sued as Toledo's assignee and subrogee, having indemnified Toledo. 
Power Co. v. Westinghouse Electric Corp., ${ }^{167}$ counsel for the utility company did argue failure of essential purpose, but to no avail. If these cases are not imstances of failure of essential purpose of the limited remedy, why not?

A first basis of distinction, adhered to by Potomac Electric, is that since Westinghouse continually exerted its best efforts, its behavior was not "willful and dilatory" and hence there was no failure of essential purpose. The weaknesses of a distinction based on the character of the warrantor's conduct have already been dealt with sufficiently; furthermore, although this distinction does differentiate Potomac Electric from J.I. Case-the source of the language employed-it does not serve to distinguish cases like Beal, in which the remedy fails to achieve its essential purpose regardless of the warrantor's "good faith."

A second distinction, and likewise one to be eschewed, is that Potomac Electric does not involve a consumer context. In unconscionability doctrine the consumer-commercial dichotomy is firmly established. ${ }^{188}$ But failure of essential purpose doctrine is aimed largely at facilitating the parties' purposes, not at policing these purposes. And cominercial entities are surely as entitled as consumers to a thoughtful construction of their contract. ${ }^{168}$

A narrower and more promising distinction might be based upon the character of goods sold: to what extent are they standard goods? Automobiles provide an example. We know that a well-functioning automobile of a given model can be produced, because the vast majority of automobiles sold are well-functioning. This proposition applies whether the automobile is sold to Hertz Corporation or to a consuner, the premise being that the manufacturing standard to which the given model must couform is independent of the status of its purchaser. Thus either a consumer or a commercial purchaser would regard as

167. 385 F. Supp. 572, 16 UCC REP. SERV. 360 (D.D.C. 1974), rev'd mem. and remanded, 527 F.2d 853 (D.C. Cir. 1975). The court of appeals reversed the entry of summary judgment and remanded with instructions to permit additional discovery; the court stated that its order was without prejudice to the right of either party to move for summary judgment upon completion of discovery, and directed that the record be returned to the appellate court following the remand proceedings. Civil No. 1794-72 (D.C. Cir., Dec. 15, 1975). It seems evident that "the validity of the legal conclusions reached by the District Court are in no way affected by the disposition of the Court of Appeals." American Elec. Power Co. v. Westinghouse Elec. Corp., 19 UCC REP. SERV. 1009, 1023 n.28 (S.D.N.Y. 1976) (Carter, J.).

168. See text accompanying note 57 supra.

169. That the case law to date has not treated this distinction may be because the leading decision, J.I. Case, imvolved a claim by a small contractor for lost profits. It should be noted, however, that J.I. Case involved a willful refusal to repair, and the consequential damages flowed directly from the defendant's continuing failure of perform. auce. The issue of recoverability of consequential damages, as a separate issue from failure of essential purpose, is discussed at text accompanying notes 189-213 infra. 
ridiculous a construction of the contract that called only for "best efforts" by the car manufacturer to make the car substantially conform to an average performance standard for the model. Although the car (despite its use in all walks of life) is preeminently a "consumer product," similar arguments should apply to the standard model of a nonconsumer good, for example, the crawler-loader involved in J.I. Case. ${ }^{170}$

As one moves into the realm of industry or commerce, however, the goods sold become more complex and more frequently customdesigned. Accordingly, a "best-efforts" standard becomes increasingly plausible. U.S. Fibres, Inc. v. Proctor \& Schwartz, Inc., ${ }^{171}$ rehed upon by Potomac Electric, ${ }^{172}$ poses an extreme case. There the plaintiff contracted to purchase an experimental conveyor-oven to produce an im-

170. Note, however, that the Magnuson-Moss Warranty-Federal Trade Commission Improvement Act, note 1 supra, is applicable only to consumer products. The Act itself defines consumer product very broadly to include tangible personal property "normally used for personal, family or household purposes . . . " The usage referred to is not the usage of the particular item, but of that type of item. Thus, under this definition, an automobile purchased by Hertz is a consumer good. For purposes of its rules of disclosure of written warranty terms and the presale availability of such terms, the Federal Trade Commission has narrowed the definition. 16 C.F.R. $\$ \S 701.1(b),(f),(h)$, 702.1(b), (e), (f). See also Statement of FTC, 40 Fed. Reg. 60170 (1975).

The discussion in note 121 supra suggests that the Act does not require that any warranty be given. It does require, however, that "written warranties" (defined to include the standard limited repair warranty) given in conjunction with consumer products be designated either "limited" or "full" warranties. The Act relies on competitive pressure to induce warrantors to give "full" warranties. It is an unfair trade practice to designate a warranty as "full" unless it meets the Federal minimum standards for warranties. 15 U.S.C. $\$ \$ 2310$ (b), 2304 (Supp. V, 1975). The minimum standards include a requirement that the warrantor remedy defects within a reasonable time or, if unable to do so, allow the purchaser to elect a refund or replacement. To this extent the Act incorporates a principle analogous to section 2-719(2) of the Uniform Commercial Code and requires results similar to Beal, discussed at text accompanying note 157 supra.

The Act does allow the exclusion of consequential damages, even in a "full" warranty, 15 U.S.C. $\$ 2304$ (a) (3) (Supp. V, 1975); however, "incidental" damages may be recoverable in certain instances. 15 U.S.C. $\$ \$ 2304$ (a)(1), 2304(d) (Supp. V, 1975). See also note 206 infra.

Although the Act limits itself to consumer products, it is not inconsistent with the proposition that one "type-transaction" involves use of a limited repair warranty in conjunction with a sale of standardized goods. All the products covered by the Act are likely to be standardized goods; the effect given to a limited repair warranty by the federal minimum standards accords with the construction of the limited remedy that this Article argues is appropriate for this type-transaction.

That the Act does not apply to all situations involving the same type-transaction is appropriate. Although a sale of a crawler-loader to a commercial entity may call for the same construction of the limited repair warranty, the Act deals with several other issues as well. The Act's disclosure rules, for instance, 15 U.S.C. $\$ 2302$ (Supp. V, 1975), are clearly tailored to the needs of a consumer, not a commercial buyer.

171. 358 F. Supp. 449, 13 UCC REP. SERV. 254 (E.D. Mich. 1972), aff'd, 509 F.2d 1043, 16 UCC REP. SERv. 1 (6th Cir. 1975).

172. 385 F. Supp. at 579,16 UCC REP. SERv. at 369 . Both cases found no failure of the respective limited remedies, due to defendants' good faith efforts, and distinguished J.I. Case on the basis of the willful behavior of defendant. 
pregnated resin pad. Although the contract described the machinery both in terms of specifications and performance standards, it was carefully drawn both to negate the imference that the description amounted to a warranty ${ }^{173}$ and to disclaim implied warranties of merchantability and fitness. The defendant did, however, extend an express warranty against defects in materials or workmanship. The contract also contained a limitation of remedy to repair or refund of the purchase price $^{\mathbf{1 7 4}}$ and excluded consequential damages.

U.S. Fibres involved an experimental item, whose attainable endquality was relatively unknown. This transaction, therefore, is poles apart from the sale of a standardized item. The court was cognizant of this distinction, for in dismissing the purchaser's clain that the disclaimer and limitation clauses were unconscionable, it stated:

In the light of the facts and commercial background of this transaction, the contract is neither oppressive nor unfair. Both parties realized that its purpose was to allocate the risks associated with

173. Although the contract contained descriptions and specificiations, it also provided:

The Purchaser agrees that any affirmations of fact, descriptions of the machine or sample or model machine herein referred to, whether or not the same relate to production or capability of the machine to perform, are not the basis of this contract, unless the word 'guarantee' is used in connection therewith.

358 F. Supp. at 456,13 UCC REP. SERv. at 262 . Discussing whether, in the face of this provision and the context of the transaction, the descriptions gave rise to an express warranty, the court of appeals stated:

If the machinery involved had been tried and proven in the manufacturing process in which Fibres intended to employ it, or if it had been sold by specification alone, the description might be held to create an express warranty .... However, the evidence fully supports the finding of the district court that the parties were attempting to put together a combination of machinery to fabricate a product by an 'unproven process.' . . . The language of description referred only to the expectations of the designers and in no way guaranteed that these expectations would be met.

509 F.2d at 1046, 16 UCC REP. SERv. at 3.

174. The relevant limitation clauses provided as follows:

4. In the event that the machine does not conform to the provisions of this contract, the Purchaser's exclusive remedy shall be as follows: Purchaser may give the Company written notice of non-conformity within ninety $(90)$ days after date of shipment. Within ninety $(90)$ days after the Company shall receive such notice, the Company shall have the opportunity of making the ma* chine conform to the provisions of this contract. If the Company is unable to do so, the Company shall, upon order in writing from the Purchaser, remove the machine as soon as practicable, refund any portion of the purchase price heretofore paid and cancel the Purchaser's obligation to pay the unpaid portion of the price in full satisfaction of the Company's liability hercunder. The Purchaser shall furnish at the Purchaser's expense a means of egress for removal of the machine.

5. The Company shall repair or replace f.o.b. Company's plant any defective parts furnished hereunder upon receipt of notice from the Purchaser within one year from the date of shipment. All labor involved in the removal and/or installation of such parts shall be at the Purchaser's expense.

358 F. Supp. at 456, 13 UCC REP. SERV. at 262-63. 
this type of transaction. When this is the case, such limitation clauses are enforced, even where one of the parties is in a superior bargaining position. ${ }^{175}$

Yet when it turned to the plaintiff's contention of failure of essential purpose, the court ignored commercial context and the impact that context might have upon the "essential purpose" of the limited remedy. Instead, it distinguished J.I. Case on the predictable ground that Proctor \& Schwartz "made numerous efforts to repair the equipment, and thus made every effort to live up to its warranty obligations."170 Although this characterization of the defendant's conduct is accurate, what appears more pertinent is the clear understanding that Proctor \& Schwartz might fail.

While U.S. Fibres represents a decided contrast to the standard goods situation, cases like Potomac Electric arguably involve goods that could fall on either side of a standard goods/custom-experimental goods distinction. On the one hand, generators are constructed and sold on a regular basis; it is not unusual to make a generator that works exactly as expected. On the other hand, the state of the art is constantly advancing, and the degree of risk mcident to failure to meet standards is considerably greater and less certain than, say, in the case of a crawler-loader. ${ }^{177} \mathrm{~A}$ court that directs its attention to such matters and inquires into the mores of the industry will be able to provide a reasoned basis for placing the transaction to one side or another of such a distinction. A court that continues to direct its attention to the moral character of the defendant cannot. ${ }^{178}$

175. Id. at 460,13 UCC REP. SERv. at 268.

176. Id. at 465,13 UCC REP. SERv. at 269 .

177. Courts are aware of this difference in context. Thus in Potomac Electric the court mentions (while discussing unconscionability) that "[O]ther than Westinghouse, there was only one other domestic manufacturer with the capability of marketing the turbine-generator ... $385 \mathrm{~F}$. Supp. at 579, 16 UCC REP. SERv. at 370. In Avenell, likewise, the court stated (in rejecting the applicability of tort theory): "[T]he turbine generator is not an ordinary consumer product, but a specialized piece of equipment ... ." 41 Ohio App. 2d at 159, 324 N.E.2d at 589, 16 UCC ReP. Serv. at 678. Although the courts recognize these characteristics of the goods as relevant to whether strict tort liability should apply, or whether limitation clauses or disclaimers are unconscionable, they do not recognize that these same factors may be-and should be-shaping their judgment on the issue of failure of essential purpose.

178. This defective analysis has two unfortunate consequences. First, it develops both an apparent and an actual split in authority. The "wilful conduct" rationale will usually be abandoned when its application does not lead to the "proper" result. See Beal v. General Motors Corp., 354 F. Supp. 423, 12 UCC REP. SERv. 105 (D. Del. 1973), discussed at text accompanying note 157 supra. A doctrinal split of authority is thus introduced, although there is not much reason to think, for example, that the Beal court would decide U.S. Fibres differently. Some courts, however, will believe that the distinction is the key to proper decision. See Lankford v. Rogers Ford Sales, 478 S.W.2d 248, 10 UCC ReP. SERv. 777 (Tex. Civ. App. 1972), discussed at text accompanymg note 
The "standard-goods" distinction rests, therefore, upon the proposition that where goods are routinely produced to a specified standard, the sale of any given unit with a promise to repair carries with it an imphed assurance that repair will be successful within a reasonable time. In part the implication may be grounded upon the reasonable expectations of the purchaser in such a situation; in part it rests upon the assumption that the burden inposed is not crushing. Since repair is usually possible, the imstances in which the seller must answer for the failure of the limited remedy will be few.

Where goods are not standardized or, in the extreme alternative, where they are experimental, both aspects of this calculus are altered. On the one hand, as goods become more unique, the reasonable expectations of the buyer become attenuated. On the other hand, the degree of risk imposed by an absolute construction of the repair duty becomes extensive. ${ }^{179}$

American Electric Power Co. v. Westinghouse Electric Corp. ${ }^{180}$ a very recent case involving the failure of yet another turbine, provides the clearest recognition to date of the importance of such a distinction:

Further, the rule that the agreed-upon allocation of commercial risk should not be disturbed is particularly appropriate where, as here, the warranted item is a highly complex, sophisticated, and in some ways experimental piece of equipment. Moreover, compliance with a warranty to repair or replace must depend on the type of machinery in issue. In the case of a multi-million dollar turbine-generator, we are not dealing with a piece of equipment that either works or

147 supra. Thus an actual split of authority develops as well: the very same case, factually, is treated differently.

The extent of the mischief should not, however, be overemphasized. In the cases to date, few results can be criticized. Nor is predictability wholly shattered-in cases of confusion or uncertainty, the common lawyer instinctively retreats to the facts. As most of us can tell a car from a steam turbine, we can live with this case law and predict the outcome of Westinghouse's next generator case. But neither should the costs of such shoddy analysis be dismissed. Clear principles of decision are not being developed; for the poor lawyer whose misfortune it is to wander into this case law for the first time, all but automobiles and turbines are "undecided cases."

179. What might be thought peculiar in the Code's treatment of this problem is the apparent disregard it exhibits toward "the contract" itself-that is, toward the written documentation of the contract. This tendency to encroach upon the "autonomy" of contract documentation, however, is not restricted to section 2-719(2). It permeates Article Two and much of modern contract law. The Code's analysis assumes that the exact same wording of a limited repair remedy may be given different effect, depending upon the commercial context in which it must be applied. To the extent that this assumption embodies a rule of interpretation, or a rule of construction that hesitates to give effect to boilerplate not tailored to the specific transaction, it is hardly remarkable. To the extent, however, that the view assumes certain "correct" prototype transactions and requires a party departing from the norms of that transaction to validate the deviation, not only in terms of assent, but also of social utility, it is quite remarkable.

180. 19 UCC REP. SERV. 1009 (S.D.N.Y. 1976). 
does not, or is either fully repaired or not at all. On the contrary, the normal operation of a turbine-generator spans too large a spectrum for such simple characterizations. ${ }^{182}$

Significantly, the court did not regard this distinction as precluding a failure of purpose of the limited repair warranty; plaintiff alleged a willful, bad faith refusal to repair, and a repudiation of the repair obligation, and the court held that the material facts still in issue required a denial of defendant's motion for summary judgment. The court relied upon the distinction to justify giving an independent effect to a clause excluding consequential dainages, and accordingly granted defendant's motion for partial sunmary judginent regarding such damages. ${ }^{182}$ A rule giving this more limited effect to the standardgoods distinction, however, does raise some questions. One of these is the extent to which terms such as "willful," "bad faith," and "repudiation" represent conclusory labels which are easily manipulated, with marginal reference to actual differences in underlying facts. A related issue is the extent to which a court may thereby sanction "repudiations" of duties that would only exist when there has already been a failure of essential purpose, and then premise the "failure of purpose" upon that repudiation. ${ }^{183}$

181. Id. at 1030-31 (footnote omitted). The contrast which the court identifies is most clearly drawn between a turbine and an automobile or other standard good. The court's footnote 42 is illuminating:

Cf. Riley v. Ford Motor Co., supra, wherein the court noted that it would

$\therefore$. agree with the appellee's contention that at some point after the purchase of a new automobile, the same should be put in good running condition, that is, the seller does not have an unlimited time for the performance of the obligation to replace and repair parts ... This is not more than saying that at some point in time, it must become obvious to all people that a particular vehicle simply cannot be repaired or parts replaced so that the same is made free from defect.'

182. The issue whether an exclusion of consequential damages can be given independent effect despite the failure of purpose of a limited remedy contained in the same contract is discussed more fully in the text accompanying notes 189-213 infra.

183. The expansive capacity of these terms was suggested as early as Jones \& McKnight v. Birdsboro, 320 F. Supp. 39, 8 UCC REP. SERV. 307 (N.D. Ill. 1970) (discussed at text accompanying note 192 infra). There the complaint alleged that defendant breached its contract to manufacture and deliver certain automated equipment, specifically by failing to design and manufacture in a workmanlike manner, and failure to redesign and remake the equipment. The court denied summary judgment for defendant, finding that there were factual issues concerning whether there had been a failure of purpose due to defendant's repudiation through willfully dilatory action.

At one point, American Electric Power is distinguished from Potomac Electric on the basis that the latter is a case where it is "undisputed" that defendant had complied with its warranty, while the former was not. To bolster this assertion, the court notes the unquestioned fact that Westinghouse had refused to replace the generator when requested to do so by AEP. This is definitely form over substance; surely a request by Potomac Electric would have met a similar fate. This is also a nice illustration of the possibilities of circular reasoning afforded: if there is a duty to replace the generator, it is one which cau only arise after the limitation to repair and replacement of parts 
Even if one accepts a standard-goods distinction, however, turbines may reasonably be included within the standard-goods category. In that event a fourth basis may be proposed for distinguishing Potomac Electric from cases finding a failure of essential purpose: that no substantial impairment of the value of the bargain exists when the plaintiff is restricted to the limited remedy. This distinction constitutes a second basis on which the Potomac Electric court rejected plaintiff's arguinent:

Nor has the plaintiff lost the substantial part of its bargain .... The unit is still operative and the increased fuel costs as stated by the plaintiff have not been excessive by any standard. ${ }^{184}$

Although a deficiency in the turbine persisted, it was, in the court's estimation, a minor one. Avenell presents an even clearer set of facts: there the breakage was a one-time occurrence. Although consequential damages of a substantial absolute amount arose, the turbine itself was returned to wholly satisfactory service. It would have been erroneous to seize upon the absolute size of the consequential damages as a demonstration that the plaintiff was being deprived of the substantial value of the bargain; ${ }^{185}$ in all of these cases the "bargain" left all consequential loss on the purchaser.

Potomac Electric is consistent with the proposition that where the contract contains a valid exclusion of consequential damages, the amount of consequential damages suffered should not enter directly into a determination whether the limited remedy has failed of its essential purpose. ${ }^{186}$ Otherwise, a limited remedy may be argued to fail of its purpose whenever substantial consequential damages occur. Such a result flies in the face of the contractual exclusion of consequential damages, validated by section 2-719(3), except where unconscionable.

has failed-and this failure can hardly be premised, therefore, on the refusal to replace the generator. Cf. Fahlgren, Unconscionability: Warranty Disclaimers and Conseguential Damage Limitations, 20 ST. Louss U.L.J. 435, 458 (1976).

It may be recalled that in Potomac Electric Westinghouse was carrying on continuing research, and applying the fruits of that research to solving the problem with the generator. This is laudable, and probably good business, but would a failure to do so itself constitute "bad faith," "willful" "repudiation" of a repair obligation?

184. 385 F. Supp. at 579, 16 UCC REP. SERv. at 369.

185. In Avenell, for instance, the claimed consequential damages were $\$ 185,000$. The value of the generator was not given, but it is not clear that the consequential damages were substantial even in relation to that value. Least of all is it clear that they were significant in terms of total operation of the unit over its useful life (in a sense, total potential consequential loss). This latter figure, if significant, would reflect itself in the current capital value of the turbine; in Avenell, capital value was apparently unimpaired.

186. When the consequential damages suffered coincide with a destruction of the unit's ability ever again to generate value, the consequential damages may appear indirectly to be entering into the determination of failure of essential purpose. But it is still the relative capital value of the goods remaining that should be determinative. 
Since such exclusions have routinely been upheld in commercial contexts, this overly broad application of section 2-719(2) would become a back-door mechanisin for reaching results the courts consider precluded under section 2-719(3). ${ }^{187}$

In summary, cases applying section 2-719(2) to limited repair warranties demonstrate some of the same weaknesses as the undiscoverable defect cases: too much is being taken for granted. Courts may well be moved by a vague apprehension of the commercial context and the manner in which it bears upon the issues before them, but they do not seek to sharpen their understanding or to explicate it in their opinions. An opportunity for development of the case law upon predictable lines of analogy is therefore lost. At the same time, freed from the requirement of delving into commercial mores, courts are utilizing unfortunate distinctions that appeal more to our sense of moral outrage than our understanding of commercial life. Where results yielded by these distinctions fortuitously accord with the results that an understanding of the commercial setting would dictate, the innnediate harm is not great. But the potential for mischief is great, both because these false distinctions continue to mask the need for a true analysis, and because of the great capacity of everyday emotion to mislead commercial judgment. All of these difficulties could be reduced were courts to adhere to the first two steps of the previously suggested analysis: a thoughtful explication of the essential purpose of the limited remedy, as informed by an understanding of the "type-transaction"; and a determination whether that purpose will be furthered by application of the limited remedy in the particular case.

An additional problem the two sets of cases share is the relationship between the unconscionability and failure of purpose doctrines.

187. This deficiency was noted in those cases dealing with undiscoverable defects. See text accompanying notes 79-87 supra. A recent case that provides an excellent example is Earl M. Jorgensen Co. v. Mark Constr., Inc., 540 P.2d 978, 17 UCC REP. SERV. 1126 (Hawaii 1975). Buyer, a construction company, purchased structural steel from seller. The contract contained a repair-or-replace provision as well as an exclusion of consequential damages. When the steel later proved defective, seller tried, but failed, to remedy the defects. Buyer suffered consequential damages and entered a counterclaim to recover these when seller sued for the price. On appeal, the Hawaii Supreme Court reversed a summary judgment in seller's favor on buyer's counterclaim. The court considered and rejected buyer's argument that the exclusion of consequential damages was unconscionable. But it then proceeded to premise a potential failure of essential purpose of the remedy upon the fact that the limited remedy will not afford buyer reimbursement for these losses:

Assuming a breach, Jorgensen had nevertheless limited its liability under the contract to replacement of defective material or to refund of the purchase price. Mark alleges that the defects in the material were not detectable until attempts to put the plates in place were made. Under these and the totality of the circumstances a refund of the purchase price would have been a totally inadequate remedy.

Id. at 987, 17 UCC REP. SERV, at 1139. 
The difficulty, however, takes a slightly different form in each context. In the case of undiscoverable defects, the danger posed is that courts, through a misapplication of failure of essential purpose doctrine, may void clauses serving the exact purpose for which they are designed and whose operation cannot be described as unconscionable. Part of this difficulty has arisen because of a judicial tendency to regard protection against consequential loss as part of the buyer's bargain, despite a valid exclusionary clause. In cases involving limited repair warranties, however, the issue has usually been posed in terms of whether failure of the himited repair warranty necessarily invalidates an exclusion of consequential damages. Alternatively, the issue may be posed in terms whether the clause can be given effect, so that consequential damages are not recoverable in circumstances where the effect of the limited remedy can be avoided in less drastic ways-for imstance, through revocation of acceptance. This perplexing question is analyzed in the next section of this Article.

\section{III}

\section{Remedies Avallable}

Assuming that a court finds that a remedy has failed of its essential purpose, it next faces the question of providing an appropriate remedy. In contrast to the opacity of the statute's first phrase, "failure of essential purpose," section 2-719(2) is refreshingly straightforward in stating the effect of such a failure: "remedy may be had as provided in this Act." Thus the full panoply of Article Two remedies appears to be available. Indeed, the cases contain little disagreement concerning the availability of damages for breach of warranty ${ }^{188}$ or, under otherwise appropriate circumstances, revocation of acceptance. ${ }^{189}$ One recurring issue, however, does plague the courts: when a warranty provision contains not only a limitation of remedy to repair or replacement, but also an exclusion of consequential damages, may the latter clause be given effect, notwithstanding the "failure" of the repair provision? One view holds that if "remedy may be had as provided in this Act," such remedies clearly include consequential damages under section 2-715. In another view, however, that the limited remedy has failed- of its purpose does not preclude the continued existence of some lesser limitations on available remedies. Also, the case law is clouded by the failure of some early cases to regard the availability of consequential damages as a separate issue from failure of the limited remedy. Moreover, these cases are ambiguous when they re-

188. UNIFORM COMMERCIAL CODE $\$ 2-714(2)$.

189. Id. § 2-608, quoted at note 127 supra. 
strict a buyer to the terms of the contract: they may be read either as finding no failure of purpose or as giving independent effect to the clause excluding consequential damages. ${ }^{190}$

\section{A. Refusal to Repair}

In J.I. Case the court awarded consequential damages through a circuitous and fictional construction of the contract. ${ }^{191}$ Jones \& $\mathrm{MC}$ Knight v. Birdsboro, ${ }^{192}$ likewise allowing consequential damages where there was a "willful" failure to repair, more accurately identified the central issue in such cases: where the bulk of the consequential damages flow directly from the failure to repair and accrue during the period of wrongful refusal, what "incentive" (in the negative sense of an avoided sanction) exists to compel compliance with the remedy, unless consequential damages are awarded?

Consider the exact facts in Birdsboro. The defendant was to manufacture and deliver automatic inachinery and equipment. The plaimtiff alleged that

[D]efendant did not design and manufacture the machinery in a workmanlike manner, that it failed to take remedial action to redesign and remake the machinery and equipment when necessary under the purchase agreement, and that plaintiff's production was therefore seriously interrupted and impaired, causing plaintiff to suffer substantial losses. ${ }^{193}$

So long as the warrantor effects repair, the purchaser will be limited to accepting repair. Under the court's hypothesis, refusal to repair constitutes a "failure of purpose" of the limited remedy, thus brimging the Code's usual remedy provisions into play.

The remedy generally available to the purchaser is damages for breach of warranty. Normally, section 2-714(2) provides the measure of such dainages:

[T] ence at the time and place of acceptance between the value of the goods accepted and the value they would have had if they had been as warranted, unless special circumstances show proximate damages of a different ainount. ${ }^{194}$

190. See, e.g., V-M Corp. v. Bernard Distrib. Co., 447 F.2d 864, 9 UCC REP. SERV. 670 (7th Cir. 1971), discussed in Koehring Co. v. A.P.I., Inc., 369 F. Supp. 882, 889, 14 UCC ReP. SERv, 368, 375-76 (E.D. Mich. 1974). See text accompanying note 161 supra.

191. See text accompanying notes 133-143 supra.

192. 320 F. Supp. 39, 8 UCC REP. SERV. 307 (N.D. III. 1970).

193. Id. at 40,8 UCC REP. SERV. at 309.

194. UNIFORM COMMERCIAL CODE § 2-714(2). 
This measure obviously provides the purchaser with some remedy: it affords compensation for the diminution in the value of the goods themselves. Furthermore, it probably provides a stronger incentive to effect repair than would a measure based simply on the costs of the repairs elsewhere. ${ }^{195}$ Nevertheless, it is a static, not a dynamic, measure of the plaintiff's loss. As it does not grow over time, it poses no greater incentive to do repairs this week than to do thein next month or next year.

Perhaps courts are bothered by the apparent quid pro quo of the limited remedy: the purchaser loses the right to consequential damages, but obtains the right to repair. If this analysis is correct, then, as in most exchange situations, only the party who performs can bind the other party to the promised "counter-performance"-the giving up of consequential damages. This rationale explains the language of the Birdsboro court:

Although the plaintiff-buyer purchased and accepted the machinery and equipment with the apparent knowledge that the seller had properly limited its liability to repair or replacement, and although the plaintiff does not allege any form of unconscionability in the transactions which led to the purchase, plaimtiff also was entitled to assume that defendants would not be unreasonable or wilfully dilatory in making good their warranty in the event of defects in the machimery and equipment. It is the specific breach of the warranty to repair that plaintiff alleges caused the bulk of the damages. This court would be im an untenable position if it allowed the defendant to shelter itself behind one segment of the warranty when it has allegedly repudiated and ignored its very limited obligations under another segment of the same warranty, which alleged repudiation has caused the very need for relief which the defendant is attempting to avoid. ${ }^{196}$

Recovery of consequential damages in such cases thus has appeal as an equitable result; however, it is equally necessary if a meaningful sanction for the defendant's breach is to be provided.

\section{B. Inability to Repair}

Cases allowing recovery of consequential damages have not been limited to those in which the court found a failure of essential purpose because of willful failure to repair. Beal v. General Motors Corp., ${ }^{107}$

195. Occasionally, defendants have argued that in the case of a limited "repair" warranty, "special circumstances" do "show proximate damages of a different amount," namely, the cost of repair. Thus far, the argument has not met with success: the plaintiff is entitled to the usual measure. See, e.g., Ford Motor Co. v. Gunn, 123 Ga. App. 2d 550, 181 S.E.2d 694, 8 UCC REP. SERV. 1180 (1971).

196. 320 F. Supp. at $43-44,8$ UCC REP. SERv. at 313.

197. 354 F. Supp. 423, 12 UCC REP. SERV. 105 (D. Del. 1973). 
while adopting the broader view that there is a failure "whenever the warrantor fails to correct the defect within a reasonable period,"198 was equally quick to allow a recovery of consequential damages. But recovery in such cases poses somewhat different problems. Defendant General Motors conceded the recoverability of "the difference in market value of a truck free of defects and the truck actually delivered." This measure, GM argued, "will give the buyer everything he had a right to expect under the contract."199 Unfortunately, GM also argued that as this measure of damages was adequate, there was no "failure of essential purpose" and therefore no right to consequential damages. The court perceived a flaw in this argument, in that the limited repair warranty did not provide for the defendant's proposed remedy, which was therefore available only if the limited repair warranty failed of its essential purpose. If such was the case, the court continued, consequential damages should also be allowed. ${ }^{200}$

It is at least arguable, however, that the court's reasoming is itself flawed. The court is correct that the failure of essential purpose gave Beal the right to section 2-714(2) damages; and GM, in conceding the propriety of such damages, implicitly conceded the failure of the more limited "repair" remedy. It is equally clear that when a remedy so fails, "remedy may be had as provided in this Act." What is less clear, however, is the appropriateness of consequential damages in this case, since the Act "provides" for consequential damages" 201 while also "providing" for their exclusion by agreement where not unconscionable. ${ }^{202}$ In short, citation to section 2-719(2) merely poses the question of the possible "independence" of a section 2-719(3) exclusion of damages.

198. Id. at 426,12 UCC REP. SERV. at 109.

199. Id. at 427,12 UCC REP. SERv. at 110 .

200. The actual text of the courts' argument reads:

The logic urged in support of this argument is flawed . . . .

Defendant concedes that plaintiff is entitled to direct damages measured by market values. What is it, however, that gives him this remedy? It is clearly not the contract, for it purports to substitute a right of replacement and repair for any right to damages. Rather, the right to direct damages arises from $\$ 2-714(2)$ of the Uniform Commercial Code. But where the parties expressly provide for an exclusive remedy "in substitution for" the "measure of damages recoverable under" the Code, that remedy is the buyer's sole recourse. $\$ 2-719$. The direct damage remedy of $\$ 2-714(2)$, therefore, in applicable only when the exclusive remedy provided in the contract fails of its essential purpose within the meaning of $\$ 2-719(2)$. Under that section when such a failure occurs recourse may be had to all the remedial provisions of the Code. There is no discernible reason for limiting that recourse to selected remedial provisions as defendant apparently attempts to do. The direct damages section, 5 2-714(2), has no greater claims to application here than does the consequential damages section $\$ 2-714(3)$, assuming, of course, that this is otherwise "a Id. proper case" for consequential damages.

201. UNIFORM COMMERCLII CODE $§ 2-715$.

202. Id. § 2-719(3). 
GM's contention, then, may be slightly restructured. Even if there is a failure of purpose of the repair remedy, entitling Beal to section 2-714(2) damages as provided by the Act, he is still not entitled to consequential damages, since those have been excluded-also as provided by the Act. Having used this rather technical argument to open the issue, GM might then have focused upon the distinctions between Beal, where consequential damages flowed from an inability to repair, and Birdsboro, involving refusal to repair.

Where consequential damages stem directly from the inability of the warrantor to repair, imposition of consequential damages cannot be justified simply on the basis of affording a sanction for breach of the duty. There is no aspect of the warrantor's conduct that should be altered. Of course, the buyer is entitled to compensation for loss of bargain, but that will be given, with respect to direct loss, by section 2-714(2). The apparent "inequity" presented when defendant's refusal to repair is willful is lacking where defendant has acted in good faith. ${ }^{203}$

\section{Consequential Damages "Unrelated" to Failure to Repair}

The facts of Henningsen $v$. Bloomfield Motors, ${ }^{204}$ a pre-Code case, suggest a third remedial situation: where the consequential damages suffered precede the failure of the limited remedy and bear no relation to it. Shortly after purchase Mrs. Henningsen's new Buick swerved off the road, seriously imjuring her and damaging the car. The warranty in question limited remedy to repair or replacement of defective parts and excluded consequential damages. Arguably, the limited remedy here failed of its essential purpose, since replacement of the single part would not have afforded the buyer a Buick of contract description. But does it follow that consequential damages should have been recoverable? Certainly, there was no need to sanction the repair duty, as there was no defective performance of the repair duty itself. Moreover, the consequential damages in question did not flow from a failure of the repair warranty. For the sake of argument, also suppose that the "defect" in the car was relatively minor and that the car itself could have been and was repaired promptly by Bloomfield Motors. Here the remedy "fails of its essential purpose" only if the substantial value of the bargain is taken to include the consequential damages that the contract excludes. If the remedy is measured simply

203. To the extent that it is artificial to draw a bright line between "refusal" and "inability", however, administrative justifications might be given to support the award of consequential damages in the latter set of cases, in order to ensure the effectiveness of remedy in the first set.

204. 32 N.J. 358, 161 A.2d 69 (1960). 
against the warranty standard of the goods sold, then the remedy does not fail of its purpose.

It is submitted that the latter view is correct and that the limitation on consequential damages should not be invalidated as having failed of its essential purpose. Of course, it is entirely possible that the limitation on consequential damages ought to fail as an unconscionable limitation. Indeed, in the Henningsen case, the Code dictates this as a prima facie result. ${ }^{205}$

\section{Reprise: Unconscionability}

What such a case poses, then, is not an issue of failure of essential purpose, but of the conscionability of the exclusion of consequential damages. That should not cease to be the issue smiply because the limited remedy fails of its essential purpose. Consider, for example, the facts of Potomac Electric and Avenell, which are somewhat similar to those in Henningsen. In Avenell there was no lasting impairment of the value of the goods; the case is thus similar to the variant of Henningsen, in which the Buick may be completely repaired, although Mrs. Henningsen may not. Potomac Electric differs, for it contained a lasting, albeit unsubstantial, impairment of the value of the goods. Thus if a substantial permanent impairment of the quality of the goods is imagined in Potomac Electric, there might be a failure of essential purpose of the remedy. Hence the utility coinpany might be allowed to revoke acceptance of the goods, and the seller might not be entitled to the price. This failure, however, should not also have the effect of rewriting the risk allocation incorporated in the consequential loss clause. ${ }^{208}$

205. UNIFORM COMMERCIAL CODE § 2-719(3).

206. If the consequential loss clause might be understood as applicable only when repair can be effected, the result would be plausible in a consumer setting. In a commercial setting, however, this understanding of the clause is not very plausible. Whether or not seller is able to repair, perhaps particularly in the latter case, seller may seek to avoid liability for the often crushing losses that may ensue when production goods fail. Avoidance of liability by the seller is regarded as permissible primarily because the buyer usually has opportunities to rearrange his operations as to ninimize loss.

The matter is perhaps less clear in a consumer setting. Such a distinction between incidental damages directly traceable to the warrantor's inability to "remedy" within a reasonable time and such incidental damages as may accrue simply while repair is being attempted is drawn by the Magnuson-Moss Warranty-Federal Trade Commission Inprovement Act, which allows the warrantor under a "full" warranty to avoid the latter, but not the former. 15 U.S.C. $\$ 2304$ (d) (Supp. V, 1975).

"Remedy" is defined as repair, replacement, or, in certain instances, refund. 15 U.S.C. \$ 2301(10) (Supp. V, 1975). Although the statute does not make an apparent distinction between "willful" refusal and inability, in fact it probably does. So long as the warrantor is trying repair, incidental damages may be precluded for a reasonable time. At the end of that reasonable time, the warrantor either replaces or refunds "reinedies"), precluding incidental damages, or else his refusal to do so becomes a will- 
Perhaps the strongest case in support of an independent effect for a clause excluding consequential damages is County Asphalt, Inc. $v$. Lewis Welding \& Engineering Corp. ${ }^{207}$ The contract was for the sale of two asphalt plants to have a productive capacity of 300 tons-per-hour; the completed plants' capacity was substantially less. The plaintiff buyer alleged that the seller had improperly erected the plants and sought damages, including consequential damages, for lost profits and losses incurred in purchasing asphalt in the open market for its own needs. The contract was subject to a limited warranty, which provided for repair or replaceinent but specifically precluded any liability for consequential dainages. The plaintiff asserted both that the clause was unconscionable and that the limited remedy had failed of its essential purpose, making all Code remedies available. The court found first that the clause was not unconscionable: the setting was commercial, the plaintiff had obtained alternative proposals from the defendant's competitors before concluding its contract with defendant, and the defendant had "substantially performed" its part of the bargain. ${ }^{208}$

The court then turned to consider the plaintiff's second contention, that the limited remedy had failed of its essential purpose:

Plaintiff has alleged various breaches by defendant of the contract at issue. If any of these breaches are proven to have occurred, the circumstances of the parties then and now will render the exclusive remedy provided wholly inadequate. Therefore, if plaintiff is entitled to any remedy at all, it is entitled to whatever remedies would be available to it "if the . . clause had never existed." Indeed, to enforce the exclusivity of the "repair and replacement" remedy in the face of any of the breaches herein asserted would be to create an unconscionable result. ${ }^{209}$

ful refusal to "remedy" (although not to "repair"). An earlier repudiation, or negligent or dilatory behavior, will probably result in a finding that the reasonable time for repair has expired, and incidental damages are thenceforth recoverable.

The Act allows the exclusion in all cases of consequential damages, provided the term is conspicuous. 15 U.S.C. $\$ 2304$ (a) (3) (Supp. V, 1976).

207. 323 F. Supp. 1300, 8 UCC REP. SERv. 445 (S.D.N.Y. 1970), aff'd on other grounds, 444 F.2d 372, 9 UCC REP. SERV. 206 (2d Cir. 1971), cert. denied, 404 U.S. 939 (1971).

208. The following excerpt contains the court's full discussion regarding substantial performance:

Defendant has evinced enough good faith in the performance of its contractual obligations to allow it to assert the exculpatory clause. Were the defendant guilty of bad faith, it might have been estopped from asserting exculpatory contractual language. Courts and commentators have used such terms as "substantial performance" or performing the "iron essence" of a contract when discussing what minimum is necessary to allow a party to raise these defenses, but the basic idea appears to be akin to "good faith." In this case, while the jury may or may not find that defendant has not performed to the letter of the contracts, the evidence does unquestionably demonstrate that defendant has "substantially performed" for the purposes of this ruling.

Id. at 1308, 8 UCC REP. SERV. at 447.

209. Id. at 1309, 8 UCC REP. SERv. at 448. 
Finally, the court concluded that even if breach-and thus failure of the exclusive remedy - were shown, the only effect would be to treat the exclusive remedy clause itself as striken from the contract: "Other clauses limiting remedies in less drastic manners and on different theories would be left to stand or fall independently of the stricken clause."210 Since the clause excluding consequential damages had already been found conscionable, it was given effect. The result in County Asphalt squares with the result on the facts in many other cases, where the decision is based exclusively upon other grounds ${ }^{211}$ or upon a finding that there has not been a failure of essential purpose. ${ }^{212}$

Although one discovers considerable case law to the contrary, this conflict is more apparent than real. For, as previously noted, it does not follow that to give an independent effect to a consequential loss clause is automatically to validate it. Instead, it remains subject to section 2-719(3); many times the clause may fail to pass muster under that section. Failure of purpose of the limited remedy is not wholly irrelevant to this determination of unconscionability; in a consumer setting, it inay contribute an element of "surprise."

Thus, in a case like Beal v. General Motors Corp., which allows consequential loss in a consumer setting, an argument may be made that any clause excluding consequential damages where repair cannot be promptly effectuated is unconscionable. The mability to effect repair is unexpected, and a consumer may have anticipated application of the clause only where repair was promptly accomplished. Substantively, it may be argued that the risk allocation is placed upon a party unable to spread it. Such arguments may not be particularly convincing; we will not know if courts truly find them so until they face them squarely, rather than retreat into a mechanical and talismanic application of the Code's language.

Furthermore, focusing upon unconscionability may allow a distinction to be drawn between willful behavior and simple inability to perform, when the issue is not failure of purpose, but recoverability of consequential dainages. Nearly all of the cases in a commercial setting

210. Id.

211. See, e.g., Southwest Forest Indus., Inc. v. Westinghouse Elec. Corp., 422 F.2d 1013, 7 UCC REP. SERV. 478 (9th Cir. 1970) (although this case rejected the unconscionability argument on the procedural ground that it had not been timely raised, the case is cited for the substantive proposition). See also Avenell v. Westinghouse Elec. Corp., 41 Ohio App. 2d 150, 324 N.E.2d 583, 18 UCC REP. SERv. 671 (1974). $A$ venell rejected an argument that the consequeutial loss was recoverable under "an implied warranty in tort," a theory which would approximate a holdiug that disclaimers of implied warranties are per se unconscionable.

212. Potomac Elec. Power Co. v. Westinghouse Elec. Corp., 385 F. Supp. 572, 16 UCC REP. SERv. 360 (D.D.C. 1974). Cf. V-M Corp. v. Bernard Distrib. Co., 447 F.2d 864, 9 UCC REP. SERv. 670 (7th Cir. 1971). 
that do allow recovery of consequential damages involve such a willful failure to perform the repair obligation. ${ }^{218}$

The courts have now accomplished the first step toward clarity, by recognizing that the issue whether a limited repair warranty has failed of its essential purpose is separable froin the issue whether a limitation of consequential damages contained in the same contract also is avoided. But having separated the issue, they have simply created two contrary, but equally inflexible, rules. Under one rule, failure of purpose avoids the exclusion of consequential damages; under the contrary rule, it does not. A second major step toward clarity must be a recognition that a firm rule relating the two issues is not needed: that the issues are not only separable, but independent. Third, the correct inquiry as to exclusion of consequential damages is whether the clause, if construed to apply to the circumstances before the court, is unconscionable. Acceptance of these three propositions may encourage some order in the case law.

\section{CONCLUSION}

Article Two has been described as "one of those rare statutes which has been drafted by a self-conscious jurisprude." ${ }^{14}$ Nowhere is this description inore justified than in the Article's provisions dealing with limitation of remedy. What section 2-719(2) prescribes is not a rule of law, but a principle in accordance with which the courts shall find the "immanent law of the transaction." presupposes such a process, it nowhere explains that process. Courts inay thus be excused a measure of uncertainty in their first attempts to apply the section. Nonetheless, if the Code is to accomplish its purpose of bringing some stability and predictability to this troubled area, courts inust improve their efforts. However skeptical we might be of Llewellyn's "natural law" methodology in commercial law, to ignore the extent to which it has informed Article Two will lead to unhappy results.

A three-step analysis has been suggested. The first, the most important, and the inost ignored step is to examine carefully the context of a particular transaction and to seek from an understanding of the transaction some further understanding of what purpose a given type of limited remedy might serve in it. The second step is to determine

213. Potomac Elec. Power Co. v. Westinghouse Elec. Corp., 385 F. Supp. 572, 16 368 (E.D. Mich. 1974); Jones \& McKnight Corp. v. Birdsboro Corp., 320 F. Supp. 39. 8 UCC ReP. SERv. 307 (N.D. Ill. 1970); Adams v. J.I. Case Co., I25 Ill. App. 2d 388, 261 N.E.2d 1, 7 UCC REP. SERV. 1270 (1970).

214. Danzig, supra note 14 at 621.

215. See note 75 supra. 
whether application of the limited remedy to the particular situation before the court furthers that essential purpose. If the remedy's purpose may no longer be furthered by its application, it remains for the court thoughtfully to fashion, from the Code's generally available remedies, relief that will most closely reproduce the contours of the parties' origmal bargain. Finally, even if the remedy's essential purpose calls for application, a third step is required: scrutiny of the remedy clause under the Code's unconscionability provisions. Adherence to this analysis may increase the burden of the courts as they grapple with the difficult ambiguities of commercial life. But this is a burden that the Code envisages and that must be shouldered if we are to produce an intelligible case law under Article Two. 